\title{
POLITYCZNO-SPOLECZNE UWARUNKOWANIA SALEZJAŃSKIEJ DZIALALNOŚCI WYCHOWAWCZO-DUSZPASTERSKIEJ W REPUBLIKACH ZWIĄZKU RADZIECKIEGO PO 1945 ROKU
}

\section{Wprowadzenie}

Wspólnota Kościoła zawsze podejmowała i podejmuje nieustannie refleksję nad swoją obecnością w świecie a tym samym rozważa skuteczność przepowiadania Ewangelii. Dla Kościoła ciagle ważne jest pytanie: w jaki sposób rozbudzać entuzjazm wiary, jaka jest najlepsza droga do uformowania odpowiedzialnych za tę misję apostołów, na miarę tych, którzy w historii Kościoła zdołali zaszczepić ziarno Ewangelii i umocnić jego wzrost? Dla postępu ewangelizacji odpowiedzialni i odważni apostołowie wiary stanowili zawsze oparcie i natchnienie. I mimo że byli to niejednokrotrnie, jak wszyscy inni, ludzie słabi, pełni ludzkich obaw, bezradni wobec nadprzyrodzonej tajemnicy, dzięki swojej dobrej woli umieli współpracować z Duchem Świętym, który prowadził ich przez życie do pełnej prawdy, a równocześnie usuwał lęk przed koniecznością podjęcia krzyża ofiary.

W 1939 roku, gdy wybuchła II wojna światowa, polscy salezjanie na terenie dwóch prowincji: św. Stanisława Kostki i św. Jacka Odrowąża, pracowali skupieni w 46 domach zakonnych, w tym w 11 placówkach duszpasterskich. W czasie wojny ponieśli ogromne ofiary. Mordowani w hitlerowskich obozach koncentracyjnych, w lagrach sowieckich na nieludzkiej ziemi, przetrzymywani i niejednokrotnie torturowani w więzieniach sowieckich i niemieckich, składali Panu ofiarę życia za polskość, wiarę, kapłaństwo, za pracę z młodzieżą w duchu św. Jana Bosko. Tego rodzaju praca, traktowana przez nich także jako wyraz patriotyzmu była przez okupantów uważana za działalność na wskroś wrogą ${ }^{1}$.

W wyniku wojny i zmian geopolitycznych w Europie przedwojenne państwo polskie, liczące w 1939 roku 35 milionów obywateli zamieszkałych na 388 tys.

* Ks. Waldemar W. Żurek - dr historii Kościoła, adiunkt w Instytucie Archiwów Bibliotek i Muzeów Kościelnych KUL.

${ }^{1}$ J. Krawiec, Powstanie Towarzystwa św. Franciszka Salezego oraz jego organizacja i działalność na ziemiach polskich, Kraków 2004, s. 162. 
$\mathrm{km}^{2}$, utraciło na swych wschodnich terenach 181 tys. $\mathrm{km}^{2}$ powierzchni z 13 milionami mieszkańców; do 1939 roku funkcjonowało tam 11 placówek salezjańskich. Utracone przedwojenne terytoria polskie na Wschodzie zostały anektowane na rzecz Związku Socjalistycznych Republik Radzieckich, pozostając przez prawie pół wieku w Litewskiej, Białoruskiej i Ukraińskiej Socjalistycznej Republice Radzieckiej².

Jedenastu polskich salezjanów, którzy po 1945 roku pozostali na „obczyźnie”, na wspomnianych terenach utraconych przez Polskę po określeniu w 1945 roku przez zwycięską Wielką Trójkę (USA, Anglia, ZSRR) granic powojennego państwa polskiego - Polskiej Rzeczypospolitej Ludowej - to salezjanie utrudzeni sianiem ewangelicznego Ziarna w płaczu osamotnienia ale nie zwątpienia. Mimo że tamtejsze zakłady salezjańskie i placówki duszpasterskie uległy likwidacji, pozostali oni na Wschodzie, by objąć opieką duszpasterską pozostających tam po wojnie na stałe Polaków i w ogóle katolików. Z perspektywy czasu są oni dzisiaj dla nas świetlanym przykładem apostołów Ewangelii, o których wspomniałem na początku.

Wspomnianych 11 salezjanów było Polakami, członkami Zgromadzenia Salezjańskiego i Kościoła, którym wypadało żyć i pracować dla Królestwa Bożego, w warunkach ekstremalnie trudnych, na terenach, gdzie po drugiej wojnie światowej postanowiono usunąć Boga z serc ludzkich.

Dzisiaj, kiedy to jest bardziej niż dotąd możliwe, należy ujawniać bolesną, a zarazem trudną prawdę o ich pracy, poświęceniu i ofiarach na rzecz głoszonej misji ewangelizacyjnej. Mimo że wiele wydarzeń i szczegółów zatarło się już w pamięci świadków, a wielu z nich, ze zrozumiałych względów, woli jeszcze dziś milczeć, my, żyjący współbracia - i nie tylko - nie możemy się zwalniać od obowiązku dokumentowania bodaj fragmentów historii tamtych polskich salezjanów, których losy i przeżycia były dotąd znane bodaj samemu Bogu i nielicznym świadkom.

Wspomniani współbracia podejmowali trud głoszenia Ewangelii i podtrzymywania nadziei, nie bacząc na różnego rodzaju niebezpieczeństwa i niepewność losu ewangelicznego Ziarna, w kraju komunistycznym, w którym Kościół w XX wieku był prześladowany, a posiew wiary w sercach i umysłach ludzkich usiłowano zniszczyć na wszelkie sposoby. Nie udało się tego uczynić komunistom sowieckim, ponieważ zwyciężyli męczennicy, a tamtejszy Kościół katakumbowy miał miliony męczenników. O tym częściowo podziemnym Kościele rosyjskim, twórca zasłużonej organizacji „Kirche in Not”, holenderski zakonnik ${ }^{3}$ napisał: „Koś-

\footnotetext{
${ }^{2}$ W. Roszkowski, Historia Polski 1914-1996, Warszawa 1997, s. 155-157; O. Terlecki, Najkrótsza historia drugiej wojny światowej, Kraków-Wrocław 1984, s. 334.

${ }^{3}$ Ojciec Werenfried van Straaten (1913-2003), podejmował inicjatywy pomocy tym, którzy byli w potrzebie. W 1948 roku zapoczątkował dzieło o nazwie Ostpriesterhilfe (Pomoc kapłanom na Wschodzie), które później przekształciło się w organizację o szerszym zasięgu działania Kirche in Not (Kościół w potrzebie). Po upadku komunizmu w Związku Radzieckiem Kirche in Not zwróciło się głównie w stronę Rosji, pomagając także prawosławnym. Obecnie wspiera chrześcijan w 140 krajach, rozpatruje rocznie ok. 9 tysięcy próśb, świadcząc pomoc ok. $70 \mathrm{mln}$ euro rocznie. W 1984 roku to dzieło zostało uznane przez Stolicę Apostolską jako publiczne i powszechne stowarzyszenie wiernych. http://www.voxdomini.com.pl/ruchy/kirche.html z 2 X 2007 roku.
} 
ciół w Rosji nie umarł. On cierpi z Chrystusem, ale też i z Chrystusem żyje". W gronie tych, którzy nie pozwolili tamtejszemu Kościołowi umrzeć, byli polscy księża i zakonnicy a wśród nich polscy salezjanie: bohaterowie i męczennicy, których sylwetki i pola ich pracy w zachodniej i południowej części Związku Radzieckiego pragnę pokrótce przedstawić.

Moje wystapienie oparłem na materiałach źródłowych i archiwalnych, głównie na relacjach żyjących parafian oraz na opracowaniach jakie do tej pory ukazały się drukiem na temat pracy salezjanów na byłych Kresach Wschodnich naszej ojczyzny, które po 1945 roku zostały zaanektowane przez Związek Radziecki.

\section{Radziecka rzeczywistość kościelna}

Po zwycięstwie rewolucji bolszewickiej w Rosji partia komunistyczna, realizując doktrynę marksizmu-leninizmu, uplasowała się jako siła przewodnia narodu i określała kierunek rozwoju społeczeństwa. Założenia partii realizowały władze państwowe. Stąd niemożliwe stało się, by państwo traktowało religię jako sprawę prywatną swych obywateli, gdyż według założenia ideologicznego partii państwo miało obowiązek walki z religią i krzewienia ateizmu. Stąd wolność religijna z kategorii prywatnej stała się kategorią polityczną, wrogą partii, a więc zwalczaną zarówno przez partię, jak i przez państwo.

Ostrze tej walki w ZSRR skierowane było również w Kościół katolicki. Jego struktury zostały zniszczone niemal całkowicie jeszcze przed II wojną światową. Taki stan utrzymał się do rozpadu Związku Sowieckiego. Resztki tej organizacji kościelnej (parafie) przetrwały na Zachodniej Ukrainie i Białorusi oraz w republikach nadbałtyckich - głównie na Litwie, gdzie władze komunistyczne dopuszczały pozostawienie struktury Kościoła katolickiego z jego hierarchią. Na tych terenach zdecydowaną większość stanowili katolicy a struktury kościelne dobrze zorganizowane cieszyły się dużym poparciem społeczeństwa, dlatego też ani lokalne władze republikańskie, ani centralne w Moskwie nie mogły tego faktu ignorować.

W 1945 roku państwo polskie utraciło wschodnie tereny II Rzeczypospolitej - Kresy Wschodnie. Przedwojenne placówki salezjańskie na wspomnianych terenach należały do dwu prowincji kościelnych: lwowskiej i wileńskiej. Domy salezjańskie w archidiecezji lwowskiej należały do południowej Prowincji św. Jacka z siedzibą w Krakowie: była to Daszawa, Drohowyże, Lwów - dwie, Brodki (filia domu lwowskiego w stadium organizacji), Tudorów (w stadium organizacji). Domy utracone z północnej Prowincji św. Stanisława Kostki z siedzibą w Warszawie położone były w archidiecezji wileńskiej: Dworzec, Kurhan, Reginów, Wilno dwie, Kamienny Most (filia Wilna, ul. Stefańska 41) . $^{4}$

Tereny archidiececji lwowskiej w większości znalazły się w 1945 roku w Ukraińskiej Socjalistycznej Republice Radzieckiej, część mniejsza pozostała

${ }^{4}$ W. W. Żurek, Możliwości i formy duszpasterzowania salezjanów w powojennej rzeczywistości na terenach europejskich republik radzieckich, „Archiwa Biblioteki i Muzea Kościelne”, 87 (2007) s. 320 . 
przy Polsce. Po likwidacji tamtejszych domów salezjańskich nie pozostał tam żaden salezjanin. Komunistyczne władze, po przejęciu obiektów i ich majątków nakazały wyjazd pracującym tam dotychczas salezjanom i w ogóle mieszkającym tam Polakom, do proklamowanej Polskiej Rzeczypospolitej Ludowej w ramach przymusowej tzw. repatriacji ${ }^{5}$.

Po wkroczeniu w lipcu 1944 roku Armii Czerwonej do Wilna, reaktywowana ${ }^{6}$ została Litewska Socjalistyczna Republika Radziecka. Automatycznie też zaczęły obowiązywać na Wileńszczyźnie założenia ideologiczne ZSRR. Archidiecezja wileńska podzielona została granicami politycznymi na część polską i radziecką, a w części radzieckiej na litewską i białoruską. Część archidiecezji wileńskiej wchodzącej w skład Litewskiej SRR liczyła 7 dekanatów: 79 parafii, 109 kościołów i kaplic, w których pracowało 212 kapłanów. Po przejściu frontu na Zachód (1944-1945) funkcjonowały tam wszystkie nie zniszczone działaniami wojennymi kościoły, prowadziły swoją działalność zakony, z więzień powrócili księża, w tym metropolita wileński abp Romuald Jałbrzykowski (1876-1955) ${ }^{7}$.

Z niepokojem oczekiwali wszyscy stosunku nowych władz komunistycznych do Kościoła katolickiego. Ten dział polityki władz sprawowała powołana w maju 1944 roku Rada ds. Kultów Religijnych przy Radzie Komisarzy Ludowych (od 1946 roku Radzie Ministrów) ZSRR, a w republikach związkowych, autonomicznych i obwodach utworzono urzędy pełnomocnika Rady ds. Kultów Religijnych.

${ }^{5}$ W. Żurek, Oddziaływanie duszpasterskie salezjanów w Kościele katolickim na Ukrainie, „Archiwa Biblioteki i Muzea Kościelne”, 85 (2006) s. 410-412; tenże, Możliwości i formy duszpasterzowania salezjanów, s. 320.

${ }^{6}$ Po zajęciu Litwy przez sowietów, dnia 21 VII 1940 roku litewski sejm ludowy uchwalił przekształcenie Litwy w republikę radziecką. Zgodnie z uchwałą Rady Najwyższej ZSRR, Litwa radziecka, 3 sierpnia tego roku weszła w skład ZSRR jako kolejna republika radziecka do momentu inwazji Niemców w czerwcu 1941 roku Roszkowski, Historia Polski 1914-1996, s. 93-94.

${ }^{7}$ Abp Jałbrzykowski Romuald, urodzony w Łętowie-Dąbie (Lomżyńskie). Studia teologiczne w Sejnach i Petersburgu, gdzie w 1901 roku przyjął święcenia kapłańskie. Od 1902 roku profesor, a od 1909 roku wicerektor seminarium duchownego w Sejnach. W 1915 roku przeniósł się z kurią i seminarium do Mohylewa. W 1918 roku został biskupem pomocniczym sejneńskim. Zorganizował w Łomży kurię i seminarium duchowne, którego został pierwszym rektorem. W 1925 roku został mianowany ordynariuszem nowo utworzonej diecezji łomżyńskiej, w 1926 roku abpem metropolitą wileńskim. W 1927 roku koronował cudowny obraz MB Miłosierdzia w Ostrej Bramie, w 1931 roku zorganizował I Kongres Eucharystyczney w Wilnie i 14 kongresów dekanalnych, w 1931 roku odbył pierwszy od 1744 roku synod archidiecezji wileńskiej, a w 1939 roku prowincjonalny. W czasie okupacji niemieckiej 1942-1944 był internowany w Mariampolu, przez rosyjskie władze komunistyczne w styczniu 1945 roku więziony na Łukiszkach w Wilnie, z powodu złego stanu zdrowia zwolniony po miesiącu, ale otrzymał zakaz opuszczania Wilna. Dnia 4 VI 1945 roku wyrokiem Kolegium Nadzwyczajnego (OSO - Osoboje Sowieszczanije, ros.) został wydalony poza granice ZSRR do Polski. Dnia 15 VII 1945 roku przybył do Białegostoku, skąd zarządzał częścią archidiecezji wileńskiej, która znalazła się w granicach Polski. Tu zorganizował kurię i sąd biskupi. Opiekował się wydziałem teologicznym oraz repatriowanym z Wilna seminarium duchownym. Zmarł 19 VI 1955 roku w Białymstoku. S. Hołodok, Jałbrzykowski Romuald, EK, T. VII Lublin 1997, k. 737, 738; A. Szot, Abp Romuald Jatbrzykowski metropolita wileński, Lublin 202; I. Mikłaszewicz, Polityka sowiecka wobec Kościoła katolickiego na Litwie 1944-1965, Warszawa 2002, s. 193. 
Urząd pełnomocnika Rady ds. Kultów Religijnych Litewskiej SRR ustanowiono 6 X 1944 roku.

Rada ds. Kultów Religijnych oraz jej pełnomocnicy mieli prawo otrzymywać od władz centralnych i lokalnych wszelkie informacje i materiały dotyczące kultów religijnych oraz powoływania komisji dla opracowania konkretnych kwestii dotyczących wyznań. Rada ds. Kultów Religijnych stosowała najróżnorodniejsze sposoby osłabienia roli i pozycji Kościoła katolickiego. Inicjowana przez Moskwę próba przeciwstawienia katolicyzmowi prawosławia - została zastapiona alternatywną propozycją utworzenia litewskiego kościoła autokefalicznego, niezależnego od Watykanu. Zaleconą metodą do realizacji tego celu było stosowanie „zdecydowanych działań wobec reakcyjnie nastawionego duchowieństwa”. W efekcie takiej polityki i wobec nielojalności duchowieństwa, już od sierpnia 1944 roku rozpoczęły się w republice litewskiej aresztowania księży katolickich $^{8}$.

Już w 1944 roku biskupi sprzeciwili się nakazowi zaprzestania katechizacji dzieci, a w październiku tego roku metropolita Jałbrzykowski nakazał katechizować dzieci w kościołach lub na plebaniach. Nie powiodła się także próba rejestracji wspólnot religijnych (parafii), wobec sprzeciwu hierarchów Kościoła. Zrealizowana została dopiero w połowie 1948 roku po przyjęciu przez Prezydium Rady Najwyższej Litewskiej SRR dekretu „O nacjonalizacji domów modlitwy i zabudowań klasztornych, a także domów mieszkalnych należących do wspólnot religijnych" z 19 VI 1948 roku. Wspomniane w powyższym dekrecie grabione obiekty były przejmowane przez lokalne oddziały gospodarki komunalnej.

W polityce komunistycznych władz w stosunku do Kościoła katolickiego rok 1948 można uważać za przełomowy. Do tego roku relacje państwo-Kościół na tyle się układały, że wierni mogli praktykować, kapłani spełniali bez większych przeszkód swe funkcje i ilość kościołów była wystarczająca. Przełomem stał się rok 1948. Dekret o nacjonalizacji domów modlitwy i zabudowań klasztornych, skuteczny zakaz katechizacji dzieci po kościołach, obowiązek rejestracji parafii i tzw. dwudziestki, czyniły te relacje bardzo restrykcyjnymi w stosunku do wiernych.

Celem polityki władz komunistycznych było podporządkowanie Kościoła katolickiego ustawodawstwu sowieckiemu. Na jej skutki nie trzeba było długo czekać. Już w czerwcu 1948 roku zamknięto większość kościołów wileńskich. Następnie władze państwowe wydały postanowienie o przesiedleniu księży z miast na wieś i pozostawieniu w parafiach miejskich wyłącznie duchownych ,,postępowych".

Wspomniany dekret z 19 VI 1948 roku był wymierzony głównie przeciw Kościołowi katolickiemu, który na Litwie przez kilka lat bojkotował polecenie rejestracji parafii przez tworzenie tzw. dwudziestek. Na gruncie litewskim rejestracja wspólnot religijnych nastąpiła po wydaniu 13 IX 1948 roku przez Radę Ministrów Litewskiej SRR uchwały „O rejestracji wspólnot religijnych i zakazie zbiorowego nauczania dzieci religii”. Niezarejestrowane wspólnoty religijne podlegały roz-

\footnotetext{
${ }^{8}$ Mikłaszewicz, Polityka sowiecka wobec Kościoła katolickiego, s. 28.
} 
wiązaniu, a świątynie, z których korzystały, zamknięciu. Kolejne akty prawne dotyczące spraw wyznaniowych wydane zostały na początku lat 60 . ubiegłego stulecia, w szczytowym okresie kampanii ateizacyjnej w ZSRR. Dnia 22 VI 1961 roku Rada Ministrów Litewskiej SRR wydała uchwałe „O wzmożeniu kontroli nad przestrzeganiem ustawodawstwa o kultach" z szeregiem rozporządzeń wykonawczych. Dnia 16 VI 1962 roku Rada Ministrów Litewskiej SRR wydała uchwałe „O zakazie kolędowania na terenie Litewskiej SRR”. Uchwała Rady Ministrów z 12 II 1965 roku uprawniała do wzmożonej kontroli nad związkami wyznaniowymi, poprzez utworzenie przy Komitetach Wykonawczych Rad w miastach i rejonach specjalnych komisji do kontroli przestrzegania ustawodawstwa o kultach. W praktyce sprowadzało się to do kontroli życia religijnego przez lokalne władze administracyjne.

Najważniejszą kwestią dla litewskich władz komunistycznych na Wileńszczyźnie była dominująca na tych terenach ludność polska. Dyrektywy w tej kwestii szły do Wilna z Moskwy, a te zdecydowały o tzw. repatriacji Polaków z terenów Litewskiej SRR. Na mocy umowy rządowej Polski i Litwy, podpisanej w Lublinie 22 IX 1944 roku przesiedlenie Polaków z Wileńszczyzny miało trwać od 1 XII 1944 do 1 IV 1945 roku Ta operacja przesiedleńcza napotkała na ogromny sprzeciw Polaków wobec przymusu opuszczenia rodzinnych stron. W samym Wilnie w 1945 roku Polacy stanowili 80 \% mieszkańców. Na dzień 20 I 1945 roku do repatriacji zgłosiło się zaledwie 7,4 tys. osób, a liczbę Polaków tam mieszkających szacowano na 380 tysięcy. Stąd ostatnie transporty Polaków wyjechały dopiero latem $1947 \mathrm{roku}^{9}$.

W ramach wspomnianej tzw. repatriacji do opuszczenia tych ziem rodzinnych zmuszani byli tamtejsi Polacy i ich duszpasterze. Wobec tych ostatnich stosowano represje, zastraszanie i szantaż. Większość duchownych wyjechała ${ }^{10}$. Ulegając temu naciskowi, na wyjazd zdecydował się także metropolita Jałbrzykowski. Na skutek takiej polityki znaczna część ludności cywilnej opuściła swoje domostwa.

Przełożony Prowincji św. Stanisława Kostki, ks. Wojciech Balawajder, uważał, że skoro tamtejsi Polacy wyjeżdżają, dalszy pobyt współbraci jego prowincji przestał być na Wileńszczyźnie konieczny. Wzywając listem z 4 V 1945 roku ks. JanaWielkiewiczazNowojelni(BiałoruskaSRR) dopowrotu, prosiładresata o prze-

\footnotetext{
${ }^{9}$ Wobec opornych stosowano środki restrykcyjne: pozbawienie kartek żywnościowych, prawa do mieszkań komunalnych, a wobec lekarzy wydajacych zaświadczenia o rzekomej chorobie Polaków, wszczynano sprawy karne. Mikłaszewicz, Polityka sowiecka wobec Kościoła katolickiego, s. 163-164.

${ }^{10} \mathrm{Z}$ liczby 212 kapłanów pracujących w 1945 roku w litewskiej części archidiecezji wileńskiej wyjechało do Polski 112 kapłanów (S. Vardys mówi o 150, abp M. Reinys o 110). Nie zawsze decyzje duchowieństwa o wyjeździe do Polski były pozytywnie oceniane przez Polaków, którzy nie podporządkowali się polityce repatriacyjnej. Ci, którzy pozostali, m.in. członkowie kapituły wileńskiej: prałaci ks. Lucjan Chalecki, Leon Żebrowski, kan. Jan Ellert, ks. Paweł Bekisz i ks. Józef Obrębski, poddani byli nadzorowi organów bezpieczeństwa, jako niebezpieczni dla władzy radzieckiej. Śledzili ich donosiciele, nawet z grona najbliższych współpracowników. A. Hlebowicz, Kościół odrodzony, Gdańsk 1993, s. 43; Mikłaszewicz, Polityka sowiecka wobec Kościoła katolickiego, s. $177-178$.
} 
kazanie tej informacji współbraciom, którzy w owym czasie pozostawali jeszcze na wschód od granicy państwa polskiego. Otrzymawszy w odpowiedzi szczegółowe informacje o procencie Polaków, którzy tam pozostali oraz o liczbie obsługiwanych kościołów, ks. Balawajder nie nalegał stanowczo na powrót: „ Nie mam nic przeciw temu, byś pozostał w dalszym ciagu jak długo Twoja praca jest dla tamtejszych parafian niezbędna". Taką samą normę zastosował inspektor wobec pozostałych współbraci. Oni sami we własnym sumieniu decydowali i odpowiadali przed Bogiem, gdzie są bardziej potrzebni: tam na wschodzie czy w kraju ${ }^{11}$. Jednak na koniec ks. Balawajder dodał: „Dlatego czekam na Was, czekam, czekam i czekam z wielkim utęsknieniem". W kwietniu 1946 roku ks. Chodanionek pisząc do ks. Pływaczyka, inspektora wschodnich domów prowincji w czasie wojny, przesyłał wyrazy przywiązania i pozdrawiał wszystkich znajomych współbraci salezjanów ${ }^{12}$.

O wielkim zrozumieniu ich decyzji pozostania na Wschodzie ks. Balawajder pisał ponownie i otwarcie miesiąc później (czerwiec 1946) do ks. Chodanionka: „Wszystkich was oczekuję jak najrychlej z powrotem jeżeli tam Wasz pobyt będzie już nieaktualny i praca po parafiach". Przedstawiał tamtym współbraciom ogromne pole pracy i możliwości w kraju: „Bardzo dużo tu roboty. Miejscowości obsadzone przez wysiedleńców często są pozbawione zupełnie opieki duszpasterskiej z braku księży"13.

W tamtejszym duszpasterstwie w litewskiej części archidiecezji wileńskiej pozostało 9 salezjanów należących do Prowincji św. Stanisława Kostki: 8 kapłanów i jeden brat zakonny. Do nich należeli księża: Michał Franciszek Bulowski, Bronisław Chodanionek, Kazimierz Ryszard Grzegorczyk, Tadeusz Hoppe, Ryszard Stohandel, Jan Franciszek Tokarski, Stanisław Toporek, Jan Ignacy Wielkiewicz, Ludwik Witkowski. Koad. Wojciech Wiertelak pracujący w kołchozie jako pracownik fizyczny, nie był postrzegany jako zakonnik. Żyjący do dziś wspominają go jako człowieka prawego, opanowanego i dużo się modlącego ${ }^{14}$.

Represje władz radzieckich skierowano przeciw zakonom, w rezultacie czego większość zakonników wyjechała do Polski, pozostawiając w swych placówkach po jednym współbracie. Na podstawie projektu uchwały Rady Ministrów Litewskiej SRR opracowanego przez litewskiego pelnomocnika Rady ds. Kultów Religijnych - Broniusa Pušinisa „O likwidacji [placówek] kongregacji zakonnych”, Ministerstwo Bezpieczeństwa Państwowego miało spowodować by do dnia 15 VII 1948 roku zniknęły z terenu republiki litewskiej wszystkie pozostawione przez kongregacje, po wyjeździe do Polski, zakonne placówki. Wśród wymienionych w dokumencie zakonników do wysiedlenia (karmelici, misjonarze, redemp-

${ }^{11}$ Wyjątek stanowił ks. Jan Kapusta, aresztowany przez sowietów 29 XI 1939 roku w Dworcu Nowogródzkim. Przebywał na zesłaniu w łagrach sowieckich, a po odsiedzeniu kary na przymusowym osiedleniu się tam. Wrócił do Polski 30 XII 1955 roku po 9-letnich staraniach o uwolnienie.

${ }^{12}$ ASIW, T. Ks. Wielkiewicz Jan, Ks. W. Balawajder do ks. J. Wielkiewicza z 8 III 1946 rokuŁódź; Żurek, ,,Jeńcy na wolności”, s. 54, 234-235.

${ }^{13}$ Żurek, „Jeńcy na wolności”, s. 54.

${ }^{14}$ Hlebowicz, Kościól odrodzony, s. 43; Mikłaszewicz, Polityka sowiecka wobec Kościoła katolickiego, s. 178. 
torysta, franciszkanin) był także nasz współbrat, ks. Stanisław Toporek. Wyszczególnieni w dokumencie zakonnicy na przełomie 1948/1949 roku zmuszeni zostali do opuszczenia Wilna. Jeśli niektórzy z wymienionych uniknęli aresztowań, to w najlepszym przypadku duszpasterzowali na parafiach wiejskich lub byli pozbawieni prawa publicznego sprawowania kultu, gdyż nie zrzekli się swej przynależności do zakonów ${ }^{15}$.

Skutkiem takiej polityki rozproszeniu uległy zakony. Zakonnicy, w tym i salezjanie, podjęli pracę parafialną, a przyznawanie się do własnej proweniencji zakonnej było zabronione. Siostry zakonne zmuszone zostały do zdjęcia habitów. Prowadziły jednak podziemne życie wspólnotowe po podjęciu pracy zawodowej na różnych stanowiskach i w rozmaitych zawodach. Prześladowania wiernych i ich duszpasterzy za wyznawanie wiary katolickiej nie złamały kręgosłupa moralnego tamtejszego Kościoła. W okresie największych prześladowań w niektórych wspólnotach parafialnych frekwencja nawet wzrastała.

Wobec duchowieństwa władze sowieckie stosowały wyszukane metody szykan: przesłuchania, wezwania „na rozmowy” w urzędach ds. kultu, regularne wizyty milicji na probostwie, groźby, perswazje, próby oskarżenia o przestępstwa kryminalne (do takich zaliczano handel dewocjonaliami), odmowę rejestracji duszpasterza (,sprawki”), odmowę zameldowania, więzienia i zsyłki do łagrów. Represjonowani byli za nieprzestrzeganie prawa sowieckiego, szczególnie w sprawach wyznaniowych: za nauczanie religii, uczęszczanie dzieci i młodzieży do lat 18 do kościoła, urządzanie procesji, niepłacenie wygórowanych podatków.

Mówiąc o pracy salezjanów na Wschodzie po 1945 roku należałoby najpierw odpowiedzieć na pytanie, dlaczego zdecydowali o pozostaniu na Wschodzie. Wszyscy oni pochodzili z centralnej i południowej Polski ${ }^{16}$, a więc nawet więzy rodzinne nie zostały przez nich uwzględnione. Kolejne pytania: na ile możliwa była praca duszpasterska w kraju rządzonym przez komunistów? Na ile możliwa była tam praca salezjańska w duchu ks. Bosko? Czy ci współbracia przez hierarchów Kościoła traktowani byli jako zakonnicy i salezjanie? Czy oni sami czuli się salezjanami i utrzymywali kontakt z przełożonymi w Polsce? Czy przełożeni w Polsce traktowali ich jako podwładnych im współbraci? Jakie mieli możliwości i na ile $\mathrm{w}$ pracy pastoralnej realizowali ideał pracy z młodzieżą $\mathrm{w}$ duchu pedagogii św. Jana Bosko? Na postawione pytanie postaram się w miarę możliwości odpowiedzieć.

Polityka władz wobec Kościoła była nieco łagodniejsza w republice litewskiej niż w pozostałych imperium sowieckiego. Mieszkała tu stosunkowo duża liczba katolików, a władze prawdopodobnie nie chciały silnej konfrontacji. Tak więc funkcjonowało tylko dla tej republiki Międzydiecezjalne Wyższe Seminarium Duchowne w Kownie ${ }^{17}$. W nim kształcili się kandydaci do kapłaństwa pochodzą-

${ }^{15}$ Żurek, Możliwości i formy duszpasterzowania salezjanów, s. 321.

${ }^{16}$ Tylko ks. Bronisław Chodanionek pochodził z wschodnich terenów archidiecezji wileńskiej, obenie Białoruś.

${ }^{17}$ Międzydiecezjalne seminarium w Kownie istniało już wcześniej, ale uchwała z 9 II 1945 roku Rady Komisarzy Ludowych Litewskiej SRR o otwarciu Kowieńskiego Seminarium Duchownego była tylko formalnością. Celem tej uchwały było zamknięcie wileńskiego „polsko-nacjonali- 
cy z litewskich diecezji. Władze komunistycne naznaczały limit studiujących w seminarium, który w roku studiów 1946/1947 wynosił 150. Chociaż liczba na pozór wydaje się wysoka, zważywszy, że dużo umierało starszych kapłanów, potrzeby były o wiele większe w skali całej republiki. W drugim seminarium w sąsiedniej republice łotewskiej - w Rydze, studiowali kandydaci z całego terytorium Związku Radzieckiego. Tam również obowiązywał roczny limit przyjęć. Zainteresowany musiał otrzymać zgodę pełnomocnika Rady ds. Kultów Religijnych na przyjęcie do tej uczelni kościelnej.

\section{a) Kontakt ze Zgromadzeniem i przełożonymi w kraju}

Decyzję o pozostaniu salezjanów na terenach Związku Radzieckiego podejmował, każdy współbrat po głębokim namyśle. Na pewno przed ostateczną decyzją nie brakowało im wattpliwości, co było korzystniejsze dla każdego z nich, dla Zgromadzenia i Kościoła, także z ludzkiego punktu widzenia. Jak wynika z dokumentów, nad ostateczną decyzją o pozostaniu zaciążyła troska o zapewnienie potrzeb duchowych tamtejszych rodaków i katolików, którzy mimo nacisków władz radzieckich nie opuścili rodzinnych stron po zmianie granic państwowych oraz nigdy nie wyrzekli się polskiej narodowości i wiary. I właśnie ze względu na nich, od 1945 roku już obywateli Związku Radzieckiego, pragnęli ci salezjanie zapewnić im opiekę duszpasterską. Były przypadki, że z niektórych parafii wyjechało do Polski zaledwie kilka procent (Ejszyszki). Tylko w jednym wypadku (u ks. Chodanionka) przemawiały dodatkowo względy rodzinne, zapewnienie utrzymania i opieki mamie Józefie. Na taką deczyję naszych współbraci przełożeni nie mieli żadnego wpływu. Mało tego, jeszcze w 1946 roku powracali ze Wschodu współbracia (ks. Henryk Czepułkowski, ks. Marian Kamiński, koad. Stanisław BacaBaczyński), a przełożeni wciąż wyczekiwali powrotu następnych, informując ich, że w Polsce otwarły się przed salezjanami duże możliwości organizowania od podstaw nowych placówek na północnych i zachodnich ziemiach (Ziemie Odzyskane), które w 1945 roku powróciły do Polski i Macierzy po przeszło wiekowej niewoli ${ }^{18}$.

Pisząc listy do przełożonych i współbraci w Polsce zawsze podpisywali się jako współbracia i salezjanie ${ }^{19}$. Do odjeżdżającego do Polski w 1946 roku współbrata, ks. Mariana Kamińskiego, ks. Bronisław Chodanionek zwrócił się z usilną

stycznego reakcyjnego seminarium duchownego i jednocześnie $\mathrm{z}$ tym rozbrojenie duchowieństwa katolickiego". Cyt. za: Mikłaszewicz, Polityka sowiecka wobec Kościoła katolickiego, s. 174. W tej sytuacji abp Jałbrzykowski nakazał przeniesienie Wileńskiego Seminarium Duchownego do Białegostoku wiosną 1945 roku.

${ }^{18}$ Żurek, „Jeńcy na wolności”, s. 55.

${ }^{19}$ „Całuję Czcigodne ręce Przewielebnego Księdza Inspektora oddany w Chrystusie - ks. Jan Wielkiewicz” (1945), „Będę pamiętał o potrzebach Zgromadzenia i Przełożonego, którego jestem oddanym w Chrystusie synem” (Chodanionek 1946), „Kochający i zobowiązany brat - ks. Jan” (Kapusta 1954), „Współbrat ks. Stanisław Toporek” (Toporek 1959), „Kochany Księże Inspektorze" (Toporek w 1975). 
prośbą, aby zapewniał wszystkich salezjanów o jego wiernej nieustającej przynależności do Zgromadzenia. A z biegiem lat odczuwał coraz większą tęsknotę za życiem wspólnym. A pisząc do ks. Pływaczyka z Ejszyszek dnia 30 VII 1946 roku zapewniał, że będzie pamiętał w memento Mszy św. o potrzebach Zgromadzenia i przełożonego, którego jest oddanym synem ${ }^{20}$.

Wprawdzie otrzymywali korespondecję z Polski ale w większości z wielkim opóźnieniem. Uskarżali się na to, że odpowiadają nieraz z wielkim opóźnieniem, „ponieważ wiadomości te docieraja do nas jak z drugiego świata, jak do ludzi żyjących poza nawiasem" (ks. Toporek do inspektora z 28 XII 1959 roku - Ławaryszki). W późniejszych latach korespondencja była utrudniona i cenzurowana. Stąd ci salezjanie lub piszący w ich imieniu świeccy do Polski podawali adresy osób postronnych ${ }^{21}$.

Okazją do podtrzymania kontaktu z współbraćmi na Wschodzie był wyjazd na Wileńszczyznę w 1956 roku neoprezbitera ks. Władysława Mikulewicza ${ }^{22}$, który po święceniach kapłańskich 29 VI 1956 roku pragnął odwiedzić rodzinne strony i krewnych na Wileńszczyźnie. Wiózł korespondencję z Polski ale została mu ona zarekwirowana na granicy. W czasie odwiedzin spotkał się z kilku współbraćmi: ks. Kazimierzem Grzegorczykiem w Łyntupach, ks. Stanisławem Toporkiem w Balingródku, ks. Tadeuszem Hoppe w Ławaryszkach. W Ławaryszkach ks. Hoppe zorganizował mu wspaniałe prymicje, na których wygłosił kazanie o powołaniu kapłańskim. Była procesja teoforyczna ze sztandarami i bielą procesyjna, uroczysty obiad i na zakończenie okolicznościowa akademia. Wszystkich nurtowało pytanie: skąd w tak trudnych czasach ks. Hoppe otrzymał pozwolenie na

${ }^{20}$ Żurek, ,Jeńcy na wolności”, s. 52.

${ }^{21}$ „Do niego [ks. Wielkiewicza - W.Ż.] można napisać ale bardzo ostrożnie. Raczej od nich można spodziewać się listów więcej obszernych... za wzór może służyć załączona pocztówka... pisana przez Jego organistę po rysyjsku" (ks. St. Baranowski do inspektora-ks. W. Balawajdra z sierpnia 1948 roku- Skarbowo); „Od ks. Jana Wielkiewicza list pisany nie jego ręką i podpisany imieniem jego staruszki gospodyni. Adres też wskazany nie prawdziwy. Taka jest ostrożność, by się nie narazić”. (ks. Baranowski do ks. Balawajdra z 14 IX 1949 roku- Florczaki); Proszę „Wprost do ks. Wielkiewicza nie pisałam... żeby nie zwrócić uwagi tamtej władzy... Posłałam na adres pewnej pani, która na mnie odpisze” (J. Michałowska do inspektora z 19 I 1953 roku- Poznań) ; „Proszę pisać odpowiedź na adres mojego szwagra, adresować po rosyjsku" (Pani Leokadia do Zofii - siostry ks. L. Witkowskiego z 29 IV 1960 roku- Krulikowszczyzna - Białoruska SRR).

${ }^{22}$ Ks. Mikulewicz, ur. 5 XII 1927 w Werkach k. Wilna. Syn Wacława i Felicji z Baniewiczów. Ostatnim transportem przybył z Wileńszczyzny w ramach tzw. repatriacji pod koniec lat 40. ubiegłego stulecia. Nowicjat salezjański rozpoczął w 1947 roku w Kopcu koło Częstochowy, gdzie złożył śluby czasowe 15 VIII 1948 roku Po ukończeniu filozofii (1948-1950) i zdaniu matury w Krakowie, odbywał praktykę pedagogiczną w Twardogórze k. Wrocławia. W latach 1952-1956 studiował teologię w Oświęcimiu, gdzie w 1956 roku otrzymał święcenia kapłańskie. Pracował w duszpasterstwie jako kapelan sióstr. W maju 1974 roku wyjechał na misje, przez Rzym, prokurę misyjną w Belgii udał się do Zairu (Kongo Demokratyczne) w Afryce. Po wypadku samochodowym przewieziony na leczenie do Belgii dnia 11 X 1986 roku i stamtąd w kwietniu 1987 roku wrócił na Litwę do upragnionego Wilna, gdzie zmarł dnia 6 X 2006 roku Pochowany na cmentarzu parafialnym w Kalwarii Wileńskiej (obecnie dzielnica Wilna). W. Mikulewicz, S. Szmidt, Znad Wilii do Konga, Kraków 2001, s. 12-13. 
zorganizowanie tak niecodziennych uroczystości. Tym bardziej że kiedy ks. Mikulewicz pragnął odprawić prymicje w swej rodzinnej parafii - Kalwarii Wieleńskiej, ówczesny proboszcz, z obawy przed restrykcjami władz, odmówił. Pozostało neoprezbiterowi odprawienie Mszy św. w parafii rodzinnej prywatnie i w gronie najbliższych ${ }^{23}$.

Przykładem wierności Zgromadzeniu u salezjanów pracujących na Wschodzie, może być, że ci współbracia (Chodanionek, Wielkiewicz) prosili przełożonego prowincji w Polsce o przysłanie pocztą Proprium Salesianorum do odmawiania brewiarza i sprawowania Mszy św. uwzględniający liturgiczne wspomnienie świętych salezjańskich i obchodzonych świąt. W tym samym liście (14 III 1947) prosił ks. Chodanionek także o przysłanie Privilegia Societatis wydrukowane a w razie braku o nadesłanie spisanych ręcznie w streszczeniu, gdyż swoje własne gdzieś zagubił (ks. Chodanionek do inspektora z 14 III 1947 roku). Ks. Jan Wielkiewicz dziękował inspektorowi, ks. Stanisławowi Rokicie za brewiarz, sukienki do puszek oraz prosił o nadesłanie mu Libellum [Proprium do brewiarza] oraz ceremonie Wielkiego Tygodnia. (Ks. Wielkiewicz do ks. Rokity z 21 I 1957 roku - Zdzięcioł)

Po śmierci każdego salezjanina na Wschodzie współbracia sąsiedzi powiadamiali przełożonych w kraju, podając informacje o latach i miejscach ich pracy po 1945 roku. To również świadczy o świadomości ich przynależności do zgromadzenia salezjańskiego.

W 1975 roku na rocznicę śmierci ks. Jana Tokarskiego odprawiono 16 grudnia tego roku w Rakowie na Białorusi Mszę św., po której dokonano poświęcenia pomnika na grobie zmarłego. W tej liturgii wziął udział ks. Stanisław Toporek z Ławaryszek, który w przemówieniu podziękował wiernym w imieniu Przełożonych Generalnych w Rzymie, przełożonych w Polsce, od żyjących współbraci kapłanów w Polsce i od rodziny, za wszelkie dobro jakie poprzez lata posługi ks. Jana w Rakowie świadczyli wierni swemu „Ojczence”. Opisując te przeżycia inspektorowi, ks. Stanisławowi Rokicie w Łodzi, prosił ks. Toporek o przysłanie nekrologu salezjańskiego, by mógł modlić się za zmarłych współbraci każdego dnia i dane te przesłać do żyjących jeszcze w rozproszeniu na Wschodzie współbraci $^{24}$.

Dowodem uznawania ich za podległych przełożonym w Polsce świadczy fakt, że po ich śmierci (ks. Chodanionka, ks. Tokarskiego, ks. Hoppe, ks. Witkowskiego) przełożeni w kraju zbierali wszelkie informacje o ich pracy na Wschodzie. Zabiegali o te materiały jako konieczne do napisania listu pośmiertnego o zmarłym współbracie. Tak więc każdy z nich traktowany był do śmierci jako współbrat należący do prowincji w Polsce ${ }^{25}$.

${ }^{23}$ Relacja ks. Władysława Mikulewicza z 10 III 2006 roku- Wilno (zb. aut.).

${ }^{24}$ ASIW, T. Ks. Tokarski Jan, Ks. St. Toporek do ks. St. Rokity z 18 XII 1975 roku- Ławaryszki.

${ }^{25}$ Po śmierci ks. Bronisława Chodanionka w Kiszyniowie, sekretarz prowincji prosił listownie ks. Witolda Golaka w Kutnie i ks. Mariana Kamińskiego w Jaciążku o napisanie o ks. Bronisławie swoich wspomnień, gdyż: ,pamięć o nim i jego bohaterskiem poświęceniu, bo padł na posterunku pracy, trzeba przekazać innym...bo jeśli po kimś, to właśnie po tych, którzy pracowali w takich 
W pierwszych latach powojennych, gdy korespondencja na wschód - do ZSRR przebiegała w miarę normalnie, w sierpniu 1946 roku przełożony prowincji, ks. Wojciech Balawajder, przesłał upominek rekolekcyjny (wiązanka duchowa) przełożonego generalnego Zgromadzenia dla wszystkich salezjanów na świecie. Ten upominek ks. Balawajder za pośrednictwem ks. Wielkiewicza skierował do pozostałych współbraci pracujących za wschodnią granicą kraju (m.in. ks. Witkowskiemu).

O dozgonnym przywiązaniu do Zgromadzenia napisał w 1957 roku z Rakowa ks. Jan Tokarski. Pracował tam jako proboszcz od 1954 roku po powrocie z łagru sowieckiego. Pojawiały się już z latami u niego dolegliwości fizyczne, które powodowały cierpienia i paraliżowały pracę duszpasterską. „Serce powoli odmawia mi posłuszeństwa, nerwy mam potargane, całymi nocami spać nie mogę, co mnie bardzo męczy...”, skarżył się w liście. „Jak rzucić powierzoną niwę? Obawiam się słów «Biada wam synowie zbiegowie». Pracy i chleba nie brak, kawałek nieba się wysłuży... Spełniam swój obowiązek jaki względem Matki Zgromadzenia zaciagnąłem... U grobu naszego Ojca ks. Bosko proszę pamiętać o wygnańcu, który $\mathrm{z}$ dala od rodziny pcha taczkę żywota"26.

Ks. Tokarski, człowiek wielkiego serca i ogromnej dobroci, zaznał wiele goryczy, wygnania i poniewierki. Opatrzność Boża nie oszczędziła mu krzyży i doświadczeń. To nie załamało go na duchu, wręcz przeciwnie - utwierdzało w wierności powołaniu kapłańskiemu i przywiązaniu do Zgromadzenia ${ }^{27}$.

W pracy duszpasterskiej w Rakowie (1954-1974) dbał ks. Tokarski o wygląd i wystrój kaplicy cmentarnej, która służyła za kościół parafialny, gdyż świątynia parafialna została zamknięta i służyła jako magazyn. Uczył wiernych pieśni kościelnych, zapoznawał ich z posłannictwem i działalnością zgromadzenia salezjańskiego, o każdej porze gotów był im służyć. W chwilach wolnych czytał i uzupełniał własną bibliotekę liczącą ok. 800 tomów.

Pracując w ,pojedynkę”, niemal całe życie kapłańskie pracował i żył poza Zgromadzeniem ${ }^{28}$, jednak zawsze czuł się jego wiernym członkiem. Z biegiem lat i pracy w specyficznych warunkach sowieckiech, analizując swoją przeszłość, życie i prace jako zakonnika, nurtował go problem odnalezienia się w czynnej wspólnocie zakonnej, gdyby taka możliwość zaistniała ${ }^{29}$. Myśląc o tym nawet skarżył się: „Boję się wrocić do życia wspólnotowego”. Te niepokoje rozwiewaly codzienne obowiązki duszpasterskie: „Za wiele pracy... Lecz kto mnie zastapi?... Ludek garnie się".

warunkach, powinna pozostać szeroka, braterska pamięć”. List sekretarza prowincji do ks. W. Golaka z 27 XI 1973 roku i do ks. Mariana Kamińskiego z 28 XI 1973 roku w Jaciążku.

${ }^{26}$ ASIW, T. Ks. Tokarski Jan, Ks. Marian Kamiński, Wspomnienie pośmiertne o śp. ks. Janie Tokarskim, s. 4.

${ }^{27}$ Tamże, s. 3.

${ }^{28}$ Tylko 2 miesiące po święceniach (16 III 1941 roku) - do połowy maja 1941 roku mieszkał w domu salezjańskim w Wilnie przy ul. Stefańskiej 41 i odprawiał w kościele pw. św. Stefana.

${ }^{29}$ Świadzczy to, że powrót do wspólnoty salezjańskiej był tematem dla niego zawsze otwartym. 
$\mathrm{Z}$ jednej strony tęsknił także do stron rodzinnych, a $\mathrm{z}$ drugiej zdawał sobie sprawę, że wyjazd z Rakowa byłby dezercją, przekreśleniem zaufania u tych, którzy szukali u niego pociechy duchowej oraz uważali go za swego ojca i przewodnika duchowego. Od brata Stanisława otrzymywał listy błagające go o powrót na stałe do kraju, zwłaszcza gdy w 1954 roku powrócił z łagru i przez trzy lata nie mógł sprawować funkcji kapłańskich publicznie. Ksiądz Jan dziękował bratu za starania, lecz odpowiedział, że nie myśli wracać. Tłumaczył: „Co jest wart żołnierz, który ucieka z powierzonego mu posterunku". Dalej wyjaśniał, że Bóg powierzył mu owieczki, czy można je porzucić? A gdyby przyszło i zdobyć palmę męczeństwa, o jakież to moje pragnienie - kończył ksiądz Jan ${ }^{30}$.

Zatroskany o księdza Jana Tokarskiego brat Stanisław szukał pomocy i poparcia w sprawię ,ściągnięcia” ks. Jana do Polski u inspektora Prowincji św. Stanisława Kostki - ks. Józefa Strusa. Przełożony prowincji odpowiedział bratu Stanisławowi: „Prośba Pana jest zupełnie zrozumiała. Jego odjazd jednak znaczy, że tamci ludzie pozostaną bez kapłana, bez pociech religijnych. Powiem Panu coś więcej - mamy już kilka wypadków, że powracający stamtąd kapłani czują się źle... ogarnia ich jakiś lęk lub niepokój, że mimo wszystko powinni tam pozostać, gdzie już nie ma mowy o zastępstwie". Brat Stanisław zrozumiał słuszność wyjaśnień przełożonego i już od 1962 roku nie nalegał. Podzielał nawet konieczność rezygnacji brata Jana $\mathrm{z}$ osobistego szczęścia $\mathrm{z}$ krewnymi na rzecz tamtejszych parafian, dla których posługa kapłana miała zasadnicze znaczenie. Na koniec wyznał: „Poniosłem wiele trudu i starań, aby Go tu można sprowadzić, jeździłem do Ministerstwa, myślałem, iż tem sprawię mu radość i pociechę, iż jest jeszcze ktoś, co stara się o niego. A tu otrzymałem od niego list pełen wymówek. Piętnaście lat upłynęło jak my się rozstali - jednakże staję się dumnym, iż mam brata bohatera. I jego słowa, a raczej listu pisanego do mnie stają mi ciągle w pamięci" ${ }^{31}$.

Przebywającego od 1942 roku na ponownej zsyłce w łagrze sowieckim ks. Jana Kapustę dręczyła myśl czy zdoła się kiedykolwiek wydostać z głębokiej Azji. Odzuwał brak informacji o Ojczyźnie, rodzimym Kościele i o drogim jego sercu Zgromadzeniu. Pragnął wiedzieć wszystko. Ogromnie się ucieszył obrazkiem Matki Bożej Wspomożycielki Wiernych jaki otrzymał. Dowiedziawszy się jak wielu współbraci zginęło w czasie wojny i zmarło odpowiedział: „Po ludzku sądząc, lepiej byłoby żeby i ja pomarl"32.

\section{b) „Sprawka”}

Postawowym warunkiem dla każdego kapłana chcącego sprawować fukcje kapłańskie było otrzymanie pozwolenia na sprawowanie czynności duszpasterskich w danej parafii - tzw. sprawki. Oczywiście każda parafia musiała wcześniej

${ }^{30}$ ASIW, T. Ks. Tokarski Jan, Stanisław Tokarski do inspektora z 16 XI 1954 roku- Miechowice Wielkie.

${ }^{31}$ ASIW, T. Ks. Tokarski Jan, Ks. Józef Strus do Stanisława Tokarskiego z 12VI 1962 rokuŁódź; Stanisław Tokarski do ks. J. Strusa z 16 XII 1954 roku- Miechowice Wielkie.

${ }^{32}$ Żurek, ,Jeńcy na wolności”, s. 126. 
otrzymać rejestrację u pełnomocnika Rady ds. Kultów Religijnych. On także wydawał księżom pozwolenia na pracę $\mathrm{w}$ danej parafii $\mathrm{w}$ charakterze wikariusza lub proboszcza. W ankiecie na rejestrację duszpasterską była rubryka o obywatelstwie. Jeśli ubiegający się pisał, że jest „obywatelem polskim”, nie mógł być zarejestrowany (podjać pracy), gdyż nie uznawał siebie za obywatela ZSRR, a tym samym nie mógł być za takiego uznawanym przez jakąkolwiek władzę.

Kapłan który otrzymał stosowne pozwolenie, mógł sprawować czynności kapłańskie na terenie swojej parafii. W przypadku angażowania się w innej parafii, np. w czasie odpustu, chcąc pomoć w spowiedzi, musiał posiadać na tę posługę specjalne pozwolenie. $\mathrm{W}$ przypadku uczestnictwa w pogrzebie na terenie innej parafii, nawet w przypadku pochówku kapłana, nie mógł występować w kondukcie pogrzebowym w sutannie lecz po cywilnemu. Na sprawowanie liturgii uroczystej - Msza św. z asystą (diakon i subdiakon) - należało uzyskać na asystę specjalne pozwolenie. Sprawa była poważna w przypadku nagłej choroby wyznaczonego kapłana, który miał na przykład wygłosić kazanie odpustowe, odprawić Mszę św. odpustową lub wygłosić rekolekcje. Według prawa nie mógł zastapić chorego nikt inny, a czas nie pozwalał na uzyskanie zezwoleni (koniec tygodnia, święta). Wówczas z reguły kapłani łamali antykościelne prawo sowieckie. Jeśli w jakiejś parafii duchowny nie przestrzegał powyższych rygorów prawa, czynił to na własną odpowiedzialność, a skutki niejednokrotnie były dotkliwe nie tylko dla niego samego, ale także dla społeczności parafialnej.

\section{c) Rejestracja parafii - tzw. dwudziestka}

Prawem sowieckim na obszarze republik radzieckich wprowadzona została rejestracja wspólnot religijnych czyli parafii a w jej ramach komitetu parafialnego, tzw. dwudziestki. Nazwa pochodzi od składu rady liczącej ok. 20 osób. Skład komitetu nie był wyrazem woli i wyboru parafian, jak to przewiduje prawo kościelne, lecz jego członkowie pochodzili z nominacji władz państwowych. Komitet parafialny w porozumieniu z pełnomocnikiem decydował o wszystkim: np. o terminie rekolekcji, doborze kaznodziei, celebransie i kaznodziei odpustowym. Członkowie komitetu zbierali składkę podczas Mszy św. (kolektę), prowadzili własne księgi finansowe i dysponowali zebranymi środkami pieniężnymi. Za ich przyzwoleniem proboszcz przeprowadzał konieczne prace i remonty w kościele i na plebanii. Oni byli dysponentami finansowymi a nie proboszcz, zarówno wobec duszpasterzy jak i osób świeckich angażowanych w parafii. Jako ludzie „nominowani” zobowiązani byli wykazać się swoją działalnością. Stąd podjęte przez parafialne komitety kościelne decyzje pozostawiały niejednokrotnie wiele do życzenia $^{33}$.

${ }^{33}$ Gdy 19 XII 1959 roku proboszcz w Łyntupach (Białoruś) nie przybył rano do kościoła i znaleziono go leżącego w łóżku w naturalnej pozycji a plecy i piersi miał sine, podejrzewano, i nie bezpodstawnie, najgorsze, m.in. pobicie przy wezwaniu do chorego w nocy. Zarówno milicja, jak i komitet kościelny nie wyraziły zgody na sekcję zwłok celem ustalenia prawdziwej przyczyny śmierci. „Jeden czarny mniej” - brzmiała odpowiedź milicji. Żurek, ,Jeńcy na wolności”, s. 69. 
Oto jeden z przykładów. Kiedy w nie wyjaśnionych okolicznościach zmarł 19 XII 1959 roku w Łyntupach ks. Kazimierz Grzegorczyk, komitetowi powiadomili księdza dziekana w Święcianach. Kiedy ten przyjechał, zastał mieszkanie księdza ogołocone. Nie znalazł kompletnie nic, ani pieniędzy, ani książki z intencjami mszalnymi, jakichkolwiek notatek. Nawet garderoby zmarłego. Potrzebne ubranie i bieliznę dla zmarłego przekazał organista łyntupski Jan Korejło. Zmarłego ubierały dwie siostry Jana: Helena i Giercia przy asyście komitetu parafialnego. Opisując okoliczności śmierci ks. Grzegorczyka do przełożonego prowincji w Łodzi, jego współbrat pracujący w Balingródku (Litwa) zakończył swój opis zdaniem: „Dlaczego Komitetowi to zrobili, to trudno dziś już wydać sąd...”34.

Utrzymanie kościoła spoczywało na parafianach. Maksymalnie mobilizowali się zwłaszcza wówczas, gdy przez jakiś czas nie było duszpasterza (Łyntupy). Wierni zbierali pieniądze by opłacić wygórowanie podatki nałożone przez władze komunistyczne. W przypadku braku kapłana na miejscu, uczęszczali do parafii oddalonych nawet kilkanaście kilometrów (z Łyntup do Święcian oddalonych o $12 \mathrm{~km}$ ), ale nie pozwalali zamknąć własnej świątyni parafialnej. Kiedy w Łyntupach miejscowy wójt - Sowiet zabrał klucze od kościoła, aby w nim parafianie nie gromadzili się na modlitwę, miejscowi katolicy na własną odpowiedzialność dorobili zapasowe klucze. W końcu oddano im właściwe, wcześniej zarekwirowane klucze ${ }^{35}$.

\section{d) Przygotowanie dzieci pierwszokomunijnych}

Gdy w 1944 roku wyszedł zakaz katechizowania dzieci w szkole, abp Jałbrzykowski polecił katechizować po kościołach i na plebaniach. I chociaż tego rodzaju praca była zakazana, nie rezygnowano $z$ tego rodzaju katechizacji, powiedzmy zakonspirowanej. W drugiej połowie lat 50. ubiegłego stulecia można mówić nawet o aktywności księży w katechizowaniu dzieci. Prowadzono wówczas grupowe przygotowanie uczniów do Pierwszej Komunii Świętej. Jak wyglądało takie przygotowanie w czasach sowieckich? Dzieci wolno było uczyś jedynie rodzicom. Wspomagali ich nieoficjalnie i z narażeniem ludzie świeccy, a raczej tercjarze lub siostry zakonne po zdjęciu habitów. Oni przygotowywali dzieci z zakresu wiedzy katechizmowej. Natomiast księża mieli jedynie pozwolenie na egzaminowanie dzieci. Stąd wielu księży pod pretekstem sprawdzania wiadomości z zakresu katechizmu, co powinno odbywać się indywidualnie, niejednokrotnie faktycznie prowadziło w kościele grupową katechizację dzieci. Tak przygotowywano dzieci w parafii Łyntupy, gdzie maluchów uczyła staruszka Wincentyna Ciuksza, tercjarka. Podobnie w parafii Ławaryszki i przy kościele filianym w Kienie uczyłaAlicja Pieślik, właściwiesiostra dominikanka. SiostraAlicjakatechizowała w kościele. Ilekroć udawała się na taką katechezę, zawsze zabierała ze sobą gruby swe-

\footnotetext{
${ }^{34}$ Żurek, ,Jeńcy na wolności”, s. 70.

${ }^{35}$ Tamże, s. 68.
} 
ter, gdyż w każdej chwili mogła wpaść milicja i zabrać ją do więzienia, a tam cieplejsze okrycie było bardzo pożyteczne ${ }^{36}$.

W czasie przeprowadzanych przez proboszcza egaminów dzieci po wielekroć były uświadamiane, jak w razie kontroli władz mają odpowiadać. Na pytanie: „kto uczy dzieci? miały odpowiadać - rodzice. A ksiądz co robi? Tylko egzaminuje”. Tak zabezpieczali się proboszczowie na wypadek niezapowiedzianych wizyt kontrolnych funkcjonariuszy państwowych. Wiadomo, że w czasie takich „egzaminów" duszpasterze uzupełniając odpowiedzi dzieci podawali im przy okazji wiele dodatkowych wiadomości katechizmowych.

Po powrocie z łagrów sowieckiech, gdzie odbywał karę przeszło 6 lat, ks. Jan Tokarski powrócił do Rakowa, dokąd przed aresztowaniem w 1948 roku w Dubrowej dojeżdżał z posługą. Za świątynię parafialną służyła wiernym niewielka kaplica cmentarna pw. św. Anny, na cmentarzu parafialnym w Rakowie. Mury tej skromnej świątyni były niemym świadkiem pracy i kapłańskiego apostolstwa ks. Jana. Tam sprawował sakramenty i celebrował liturgię. $Z$ powodu restrykcyjnych przepisów ks. Jan zdecydował, że do Pierwszej Komunii Świętej będzie przygotowywał każde dziecko indywidualnie. Nie była to więc regularna katecheza, której nie wolno było prowadzić, ale indywidualne nauczanie prawd wiary poszczególnych dzieci i starszych, jako warunek przystąpienia do I Komunii świętej ${ }^{37}$.

\section{e) Ministranci}

Nie było wówczas ministrantów w wieku szkolnym, ze względu na zakaz uczęszczania młodzieży szkolnej do kościoła. Zastępowali ich ministranci starsi, nawet panowie w poważnym wieku, których w niejednej parafii (Łyntupy, Ławaryszki, Kiena, Odessa) salezjanie zdołali zgromadzić pokaźną liczbę. Ministranci młodsi pojawili się póżniej, po „odwilży” w roku $1956^{38}$.

Przez całe swoje życie kapłańskie ks. Hoppe w pracy duszpasterskiej zwracał szczególną uwagę na ministrantów. Od początku pracy kapłańskiej, na drugiej placówce duszpasterskiej w Porudomino (1943-1947), prowadził wzorowo służbę ołtarza. Bogatym przeżyciem dla parafian były nieszpory niedzielne śpiewane po polsku, które w tej parafii właśnie on zapoczątkował, gdyż do tej pory śpiewano psalmy po łacinie. Ceremonie były przygotowywane starannie. Na specjalnie przygotowanym tronie siedział celebrans, obok miejsca dla 24 ministrantów. $\mathrm{Na}$ zakończenie śpiewu każdego psalmu na: Chwała Ojcu i Synowi ... ministranci wstawali, czyniliukłon do Najświętszego Sakramnetu, następnie do celebransa i siadali. W ocenie parafian te ceremonie były przygotowane solidnie, wywoływały przeżycie, które pamiętają do dzisín ${ }^{39}$.

W małej miejscowości Kiena na terenie parafii Ławaryszki, gdzie funkcjonowała kaplica dojazdowa, za proboszczowania ks. Hoppe (1954-1958) liczba mini-

\footnotetext{
${ }^{36}$ Tamże, s. 67, 93; Relacja Haliny Kisielowej z 7 IX 2007 roku- Ławaryszki (zb. aut.).

${ }^{37}$ Żurek, , Jeńcy na wolności”, s. 191.

${ }^{38}$ Tamże, s. 67; Relacja Haliny Kisielowej z 7 IX 2007 roku- Ławaryszki (zb. aut.).

${ }^{39}$ Żurek, ,Jeńcy na wolności”, s. 84.
} 
strantów dochodziła do 80 . Ks. Hoppe organizowanie ministrantów i bieli procesyjnej uważał za szczególnie ważne w oddziaływaniu duszpasterskim i formacji duchowej, gdyż oni w czasie liturgii i procesji byli najbliżej Najświętszego Sakramentu - jak powtarzał.

\section{f) Biel procesyjna}

W duszpasterstwie ks. Hoppe wielką wage przywiązywał do organizowania bieli procesyjnej. Dziewczęta i panienki ubrane w białe suknie z wiankami na głowie brały udział w procesjach, stąd nazywano je pospolicie procesjankami. $\mathrm{Na}$ każdej placówce, gdzie pracował ks. Hoppe, bieli procesyjnej było bardzo liczne grono. Np. w 1955 roku w Ławaryszkach pod Wilnem biel liczyła 120 dziewcząt, stąd ich kierowniczkę Walerię Rynkównę z Osienik nazywano setnikiem. Procesjanki nie mogły się spóźnić do kościoła, gdyż wówczas nie mogły uczestniczyć $\mathrm{w}$ procesji teoforycznej. Jeśli któraś z procesjanek nie przyszła $\mathrm{w}$ tygodniu do robienia wieńców na procesje, nie mogła potem iść w procesji z wieńcem. Procesje teoforyczne urządzał w parafii w Ławaryszkach raz w miesiącu. Jeśli aura była deszczowa, procesja odbywała się wewnątrz kościoła ${ }^{40}$.

Oczywiście ks. Hoppe miał wiele kłopotów z władzami. Głównie za kazania, podsłuchiwane przez szpicli donoszących władzom. Dalej za organizowane procesje z udziałem młodzieży, za liczne grono ministrantów i za pracę z młodzieżă, która tłumnie uczęszczała do kościoła. $Z$ tego powodu często on, jak i jego współpracownicy byli wzywani na przesłuchania. Kiedyś nawet zatrzymano go na dwa dni $\mathrm{w}$ areszcie.

Zastanawiające jest dlaczego np. w parafiach gdzie pracował ks. Hoppe młodzież szkolna uczęszczała do Kościoła. Jak relacjonują dziś byli parafianie, w dużej mierze zależało to od postawy odważnej księdza. Jeśli był pewny i nie bał się, władze nie ingerowały tak ostro lub ingerowały ostrożniej. Doskonale orientowały się, że za. Hoppe młodzież „poszłaby w ogień” - powtarzają byli parafianie.

\section{g) Dzieci i młodzież szkolna}

Prawo zabraniało dzieciom i młodzieży w wieku szkolnym (do lat 18) uczęszczać do kościoła. Tego pilnowała miejscowa milicja i nauczyciele szkolni, którzy stali przed drzwiami kościoła i zawracali z drogi. Nieposłusznych zapisywali nazwiska a następnie wzywali rodziców i straszyli rozmaitymi konsekwencjami. Nazajutrz na apelu szkolnym takie dzieci były wyczytywane, naśmiewano się z nich i znęcano psychicznie wobec wszystkich uczniów i grona pedagogicznego ${ }^{41}$.

Niejednokrotnie ci funkcjonariusze nie byli aż tak rygorystyczni, stąd dzieci nierzadko przeskakiwały mury ogrodzenia kościoła, a nauczyciele usiłowali ich „nadaremnie” zawrócić (Łyntupy). Można powiedzieć, że mimo odgórnego zaka-

\footnotetext{
${ }^{40}$ Tamże, s. 92.

${ }^{41}$ Relacja Haliny Kisielowej z 7 IX 2007 roku- Ławaryszki (zb. aut.).
} 
zu, decydowali lokalni potentaci i stróże prawa, niejednokrotnie z korzyścią dla młodych parafian. Do parafii Przemienienia Pańskiego w Porudomino należało przed 1939 roku przeszło 30 wiosek i osad. Dojeżdżającego z Rudnik do Porudomino pod koniec lat czterdziestych ubiegłego stulecia ks. Stanisława Toporka wspominają jeszcze żyjący parafianie; opowiadają że cichaczem młodzież uczestniczyła we Mszy św. i nabożeństwach a milicja specjalnie nie szykanowała ${ }^{42}$.

\section{h) Udzielanie sakramentów świętych}

Kapłan i duszpasterz, jeśli otrzymał tzw. sprawkę, mógł udzielać sakramentów świętych wyłącznie we własnej parafii, na którą otrzymał pozwolenie do sprawowania czynności duszpasterskich. Było to bardzo dotkliwe zarządzenie. W przypadku np. odpustu, jeśli zjeżdżali się kapłani, nie mogli oni sprawować funkcji kapłańskich, pomagając przy spowiedzi. Jeśli to czynili, to na własną odpowiedzialność i ryzyko, a konsekwencje spadały na nich i parafie gdzie sprawowali funkcje kapłańskie „bezprawnie”. Z reguły nie przestrzegano tego zakazu przy pogrzebach kapłanów. Przybyli na pogrzeb konfratrzy spowiadali thumy penitentów pragnących posługi sakramentalnej, w momencie gdy grzebali swojego duszpasterza, a o mianowaniu następcy nic pewnego nie wiedzieli.Tak na przykład w czasie pogrzebu ks. Grzegorczyka 22 XII 1959 roku w Łyntupach kapłani bez pozwolenia wyspowiadali rzesze wiernych. W czasie uroczystej Mszy św. pogrzebowej kapłan ogłosił wiernym, aby do Komunii św. przystapili wszyscy, bo po tej Mszy św. już nie będzie Przenajświętszego Sakramentu w ołtarzu. Lud zrozumiał co to znaczy. Niemal wszyscy rozpłakali się głośno. To nie płakali ludzie uczuciowi, ale płakały ich dusze ${ }^{43}$.

W przypadku pogrzebu kapłana jeden z okolicznych konfratrów otrzymywał zezwolenie do prowadzenia liturgii pogrzebowej. Zabronione było sprawować uroczystą liturgię mszalną w asyście (diakon, subdiakon - in tres) bez zezwolenia. Nie zawsze tego zarządzenia przestrzegano. Jeśli decydowali się księża na Mszę św. z asysta, to był to wyraz ich odwagi ${ }^{44}$. W kondukcie pogrzebowym przyjezdni kapłani szli w ubraniach cywilnych z biretami na głowie, jeśli aura była chłodna. Pochód na cmentarz odbywał się w ciszy, aż do bramy cmentarza, gdyż taki był nakaz władz. Na używanie dzwonów kościelnych w czasie pogrzebu kapłana należało także uzyskać stosowne zezwolenie pełnomocnika. Uzyskiwanie zezwoleń często było monetą przetargową między pełnomocnikiem a wiernymi ze swoim proboszczem - coś za coś.

${ }^{42}$ Żurek, ,Jeńcy na wolności”, s. 212; Relacja Haliny Kisielowej z 7 IX 2007 roku- Ławaryszki (zb. aut.).

${ }^{43}$ Podobnie spowiadali bezzezwolenia przyjezdni kapłani na pogrzebieks. Wielkiewicza w Zdzięciole 16 III 1969 roku Żurek, ,Jeńcy na wolności”, s. 71

${ }^{44} \mathrm{~W}$ tamtych czasach nie odprawiano koncelebry. Na pogrzebie ks. Jana Wielkiewicza w Zdzięciole dn. 16 III 1969 roku księża sami zdecydowali o mszy uroczystej. Diakonem był ks. Chodanionek z Kiszyniowa. Żurek, ,Jeńcy na wolności”, s. 262. 
Odejście z tego świata tamtejszych niektórych salezjanów lub okoliczności ich śmierci (ks. Bulowski, ks. Grzegorczyk) do dziś pozostają tajemnicą. Na ten temat krążą różne wieści i hipotezy, jednak brak jest zdecydowanego potwierdzenia faktów przez świadków. Może otwarcie tajnych archiwów KGB pozwoli w przyszłości ujawnić całą prawdę o tamtych czasach i ludziach.

Zabronione było w tamtych czasach prowadzenie przez kapłana konduktu pogrzebowego z domu żałoby do kościoła, a po mszalnej liturgii pogrzebowej na cmentarz. Wyjątek stanowił pogrzeb kapłana. I tak w czasie pogrzebu ks. Jana Tokarskiego w Rakowie na Białorusi dnia 19 XII 1974 roku naczalstwo wprawdzie zezwoliło iść kapłanom w kondukcie pogrzebowym, ale po cywilnemu, bez liturgicznych śpiewów pogrzebowych i bez bicia dzwonów kościelnych w drodze konduktu z kościoła na cmentarz ${ }^{45}$.

Kapłani często udzielali sakramentów świętych, głównie chrztu św. prywatnie po domach. Pracownikom państwowym nie wolno było chrzcić dzieci oficjalnie w kościele. W obawie przed konsekwencjami zawodowymi, dla bezpieczeństwa organizowano chrzest prywatny. Podobnie było z nauczycielami. Za ochrzczenie dziecka w parafii nauczyciel był zwalniany z posady. Do sakramentu bierzmowania żadnego przygotowania nie było. Gdy zdarzyło się, że do parafii przyjeżdżał biskup, wówczas zgromadzeni wierni ustawiali się w kolejce i przyjmowali sakrament dojrzałości chrześcijańskiej. W przypadku sakramentu małżeństwa również przyjmowano go na „terenie obcym”. I tak z Wileńszczyzny wyjeżdżali wierni np. na Białoruś, bo tam mieli znajomego kapłana i tam przyjmowali sakrament małżeństwa. Jedynie przyjmowanie sakramentu chorych dozwolone było bez ograniczeń. Kapłan, jeśli był w danej parafii, udzielał tego sakramentu na miejscu i w sąsiednich parafiach bez ograniczeń, jeśli była taka potrzeba ${ }^{46}$.

Podobnie miała się rzecz z odprawieniem liturgii pogrzebowej. Ksiądz często odprawiał najpierw prywatnie liturgię pogrzebową w domu zmarłego, a następnie odbywał się ceremoniał państwowy. Ks. Hoppe w Odessie zapoczątkował jeszcze dodatkową praktykę oprócz wcześniejszej pogrzebowej ceremonii kościelnej. Jeśli pogrzeb odbywał się na prowincji, a odbywał się z różnych względów bez kapłana, proboszcz przez zaufaną osobę posyłał w pudełku po zapałkach poświęconą ziemię. Tę wsypywano do mogiły i w ten sposób zastępowało to poświęcenie grobu. Tak praktykował wiele razy ks. Hoppe w Odessie i na obszarze kilku województw. Wierni niejednokrotnie sami przybywali do księdza z prośbą o poświęcenie ziemi, którą następnie wysypywano już na istniejące groby aby je „poświęcić" ${ }^{47}$.

Także ze względów zdrowotnych salezjanie udzielali sakramentów św. prywatnie, np. na plebanii. Ks. Bulowski pracujący w parafii Rubieżewicze (19521955) na Białorusi ze względu na otyłość zapadł na cukrzycę. $Z$ trudem poruszał się, dlatego odprawiał także Mszę św. w mieszkaniu. Z tych samych względów parafianie przynosili mu do mieszkania dzieci, gdzie udzialał im sakramentu chrztu św.

\footnotetext{
${ }^{45}$ Żurek, ,Jeńcy na wolności”, s. 196.

${ }^{46}$ Relacja Haliny Kisielowej z 7 IX 2007 roku- Ławaryszki (zb. aut.).

${ }^{47}$ Żurek, Oddziaływanie duszpasterskie salezjanów, s. 414.
} 
Najbardziej bodaj było cenzurowane głoszenie kazań. Niejednokrotnie duszpasterze nie sądzili, że za pewne wypowiedzi z ambony można ponieść surową karę. Przykład: kiedy radziecki astronauta Jurij Gagarin odbył dnia 12 IV 1961 roku na Wostoku I lot po orbicie około Ziemi - był to pierwszy w dziejach ludzkości lot człowieka w przestrzeń kosmiczna - ks. Jan Tokarski w Rakowie, komentując w kazaniu to wydarzenie, stwierdził, że od tysiącleci spoglądamy na ten świat i chcemy go zdobywać, a człowiek niestety jest coraz mniejszy. Wieczorem tego dnia przyjechała „władza” a ks. Jan za taki komentarz wyczynu kosmicznego na pięć lat został zawieszony w czynnościach duszpasterskich. W tym czasie Mszę św. odprawiał prywatnie $\mathrm{w}$ mieszkaniu, właściwie na werandzie domu $\left(3 \mathrm{~m}^{2}\right)$. Przychodzili potajemnie nieliczni, zwłaszcza na pierwszy piątek. W tym czasie potajemnie udzielał sakramentów świętych. Np. gdy był pozbawiony sprawki, wychodził z psami na spacer do lasu i tam w czasie przechadzki spowiadał penitentów. Poźniej gospodyni, pani Michalina Stankiewicz, zanosiła im komunię świętą po Rakowie i okolicy (głównie do tercjarzy) ${ }^{48}$.

\section{i) Praca z mlodzieżą}

Ze szczególnym zamiłowaniem ks. Tadeusz Hoppe w ciagu całego swego życia salezjańskiego oddawał się pracy z młodzieżą. Taki dał się poznać już od pracy na pierwszej parafii w Rudnikach (od kwietnia 1943 roku). Dość często po niedzielnej Mszy św. organizował z pomocą młodzieży szkolnej dla parafian imprezy kulturalne. Na ich program składały się przedstawienia teatralne, anegdoty, muzyka. Na takich imprezach młodzież występowała ubrana w stroje ludowe polskie. Cały program aranżował proboszcz - ks. Hoppe. Z tej okazji członkinie komitetu kościelnego (dwadcatki) przygotowywały wspólny obiad zarówno dla młodych artystów parafialnych jak i dla widzów-parafian. Tak zorganizowane i przygotowane biesiady ze wspólnym obiadem i zabawą parafianie rudniccy przeżywali ze swoim proboszczem kilka razy w ciagu roku.

Dlatego ks. Hoppe oddawał się tej pracy bez reszty. Młodzież przepadała za nim. A dzieci w kościele cisnęły się jak najbliżej ołtarza. Wówczas ks. Tadeusz zmuszony był niejednokrotnie przesuwać je w głąb kościoła. Dla młodzieży urządzał ogniska i na nich wspólnie się z nią bawił. Był zawsze wesoły i uśmiechnięty. „Po prostu nie można go było obrazić” - tak wspominają go do dziś już dorośli byli parafianie. Jako salezjanin gromadził wokół siebie tłumy młodzieży. Niektórzy parafianie okazywali zdziwienie, że „zadaje się z młodymi”. Wszystkich cenił jednakowo i każdego starał się dowartościować, wspomina jego sąsiad, ks. prałat Józef Obrębski z Mejszagoły. Wierni z parafii Ławaryszki, gromadzący się w kaplicy dojazdowej w Kienie, mówiąc o ks. Hoppe do dziś powtarzają: „Jako salezjanin nie szczędził czasu na pracę z młodzieżą". Taką opinię potwierdzali ówcześni konfratrzy i sąsiedzi ${ }^{49}$.

\footnotetext{
${ }^{48}$ Żurek, ,Jeńcy na wolności”, s. 192-193.

${ }^{49}$ Tamże, s. 83, 92.
} 
Podobnie było na innych parafiach. W Kalwarii Wileńskiej (1949-1954), parafii pielgrzymkowej, oddawał się bez reszty pielgrzymom przybywającym z różnych stron. Byławo, że niekiedy przybywało na Kalwarię nawet 15 zorganizowanych pielgrzymek dziennie. Każdą z nich witał, prowadził na adorację Najświętszego Sakramentu. Władze komunistyczne czyniły wszystko, aby zlikwidować to miejsce pielgrzymkowe w Kalwarii Wileńskiej. W tych działaniach władzom pomagała wroga Kościołowi prasa. Po odejściu stamtąd ks. Tadeusza w lecie 1954 roku Kalwaria zaczęła przeżywać stan regresu i do tej pory się nie dźwignęła ${ }^{50}$.

Ks. Hoppe był wspaniałym mówcą i kaznodzieją. Swymi kazaniami porywał zarówno starszych jak i młodzież. Parafianin z Kalwarii Wileńskiej, Stanisław Żukowski, jako młodzieniec streszczał płomienne kazania ks. Tadeusza. „To był legendarny ksiądz" - kończy wspomnienie pan Żukowski, obecnie współbrat, koadiutor salezjański w Oświęcimiu. Najprawdopodobniej dzięki takiej formacji zdecydował się pan Stanisław zostać salezjaninem ${ }^{51}$.

W szkole w Kienie nauczyciele usiłowali wpłynąć na uczniów by ci zdjęli medaliki i krzyżyki z szyi. Młodzież stanowczo zaprotestowała, tłumacząc, że nie mogą tego uczynić, gdyż należą do Krucjaty Eucharystycznej. Władze szkolne usiłowały następnie wpłynąć na rodziców aby spowodowali usunięcie medalików przez ich dzieci. Panowało powszechne przekonanie, że jest to skutek pracy i oddziaływania na wiernych i młodzież ich duszpasterza - ks. Hoppe ${ }^{52}$.

Gdy sprawa medalików ucichła, powstał nowy problem - chodzenie dzieci i młodzieży do kościoła. Według prawa państwowego było to zakazane do lat 18 . W nagonce na proboszcza ponownie stanęli w jego obronie rodzice. Na zarzuty władz ks. Hoppe odpowiadał, że „dzieci nie będzie wyrzucał ze świątyni jeśli je tam zauważy". W pewnym okresie władze planowały wywieźć księdza na zesłanie, do Rosji. Uczciwi urzędnicy - Rosjanie - uprzedzili go. Podpowiadali mu, by ze wzglądu na własne niebezpieczeństwo, wyjechał na Ukrainę. Skorzystał z tej możliwości w grudniu 1958 roku $^{53}$.

Po ks. Hoppe księża obawiali się przejmować parafię, przeczuwając, że nie sprostają poziomowi duszpasterstwa wypracowanemu przez niego. Z drugiej strony trudno jest przypuszczać, że władze nie orientowały się jak wygląda jego praca duszpasterska na co dzień i jakie chociażby głosi kazania. Można sądzić że przez wiele długich lat to mu się udawało lub w jakiś sposób było „tolerowane”. Aż wreszcie przyszedł moment krytyczny, a dla ks. Tadeusza nadarzyła się okazja wyjazdu do pracy w odległej republice ukraińskiej. Kiedy biskupwi Julionasowi Stepanowičiusowi z Wilna, który poszukiwał duszpasterza do Odessy, ks. Tadeusz zgłosił swą osobę, zdziwiony biskup odpowiedział, że tam to nie Litwa i z pewnością wkrótce go wyrzucą za jego kazania. Również pełnomocnik Rady

${ }^{50}$ Relacja ks. J. Obrębskiego z 14 III 2006 roku- Mejszagoła (zb. aut.).

${ }^{51}$ W. W. Żurek, Działalność duszpasterska ks. Tadeusza Hoppe w Odessie, w: Polacy na Krymie, red. W. Walewander, Lublin 2004, s. 214.

52 Żurek, Działalność duszpasterska ks. Tadeusza Hoppe w Odessie, s. 215; Relacja ks. J. Obrębskiego z 14 III 2006 roku- Mejszagoła (zb. aut.).

${ }^{53}$ Żurek, ,Jeńcy na wolności”, s. 92; tenże, Działalność duszpasterska ks. Tadeusza Hoppe w Odessie, s. 222. 
ds. Kultów Religijnych bardzo się zdziwił, ale pozwolenie na wyjazd wystawił ${ }^{54}$. Na początku grudnia 1958 roku ks. Hoppe opuszczał Ławaryszki udajac się do Odessy, miasta obwodowego w Ukraińskiej SRR, wielkiego portu nad Morzem Czarnym. Dnia 8 grudnia tego roku objął kościół pw. św. Piotra i Pawła, tzw. pofrancuski. Tego dnia ogłosił tamtejszym wiernym, że pozostanie u nich do śmierci. Słowa dotrzymał. Zmarł w Odessie dn. 10 XI 2003 roku

\section{Rozproszenie salezjanów na terenie republik radzieckich}

Z czasem warunki zewnętrzne i potrzeby wiernych sprawiały, że salezjanie rozproszyli się po rozległym terytorium zachodniej części Związku Radzieckiego. Do Białoruskiej SRR udali się księża: Ludwik Bulowski, Kazimierz Grzegorczyk, Jak Tokarski, Jan Wielkiewicz, Ludwik Witkowski. Do Mołdawskiej SRR wyjechał w 1949 roku ks. Bronisław Chodanionek, do dalekiej Odessy nad Morzem Czarnym w Ukraińskiej SRR w grudniu 1958 roku udał się ks. Tadeusz Hoppe. Reszta pozostała na Wileńszczyźnie.

Od początku lat siedemdziesiątych ubiegłego stulecia wyjazdy na Wschód nieco zliberalizowano, stąd i przełożony prowincji korzystał z turystycznych wyjazdów na zaproszenie, by odwiedzić tamtejszych współbraci. W 1973 roku ks. Stanisław Rokita jako osobisty delegat Przełożonego Generalnego na prowincje polskie odwiedził na Wileńszczyźnie m.in. ks. Stanisława Toporka pracującego w Ławaryszkach $\mathrm{k}$. Wilna. W czasie tej wizyty spotkał się także z innymi współbraćmi pracującymi w Związku Radzieckim ${ }^{55}$.

Do salezjanów pracujących w sowieckich republikach udawali się w latach siedemdziesiątych ubiegłego stulecia salezjanie z Polski turystycznie i na zaproszenie. Do nich należał ks. Stanisław Wilk, ks. Stanisław Szmidt, ks. Józef Gregorkiewicz. Oprócz odwiedzin służyli tamtejszym wiernym z posługą sakramentalną na możliwy sposób i głosili Słowo Boże, np. przeprowadzali rekolekcje dla sióstr (ks. Szmidt, ks. Gregorkiewicz).

Na Wschód udawali się także krewni z Polski tamtejszych współbraci, przywożąc ze sobą za żelazną kurtynę dewocjonalia, obrazki, książki religijne a szczególnie wiadomości o sytuacji Kościoła w Polsce i w świecie

${ }^{54}$ Urzędnik jakby zabezpieczając się polecił biskupowi, aby przez pół roku nie mianował do Ławaryszek po ks. Hoppe proboszcza, gdyż ks. Hoppe na pewno zostanie usunięty z Odessy za kazania. W marcu 1959 roku został mianowany ks. Antoni Dziekan. Żurek, Działalność duszpasterska ks. Tadeusza Hoppe w Odessie, s. 222-223.

${ }^{55}$ Przyleciał samolotem z Kiszyniowa ks. Bronisław Chodanionek, aby się polecić modlitwom i pożegnać za prośrednictwem przełożonego ze współbraćmi w Polsce. Wyglądał na wycieńczonego i chorego. Ten wyjazd kosztował go po powrocie trzy tygodnie leżenia w łóżku. Było to prawdziwe pożegnanie. W listopadzie tego roku zmarł. (,Jeńcy na wolności”, s. 47). Gdy leżał w trumnie, w ręku trzymał obrazek Matki Boskiej Wspomożycielki, podarunek od ks. Rokity przy pożegnaniu w Ławaryszkach. Ten podarunek był paszportem przynależności jego do Zgromadzenia. Żurek, „Jeńcy na wolności”, s. 47, 50. 
Wreszcze organizowane były jakby specjalne ekipy ludzi świeckich do przerzutu na Wschód przedmiotów kultu religijnego. Do tego przedsięwzięcia angażowano życzliwych i znajomych celników granicznych, dzięki którym kolejarze polscy przewozili znaczne ilości dewocjonaliów, szat liturgicznych a nawet monstrancję do ks. Hoppe w Odessie, której celnicy nie odważyli się otworzyć i skontrolować. Taka ekipa powstała w Przemyślu w 1988 roku. Zainicjowała ją kolejarska rodzina Adama i Janiny Boczar, którzy wraz z synami Marianem i Andrzejem, także kolejarzami, przewozili do Odessy ks. Hoppe potrzebne paramenty kościelne, dewocjonalia, książki religijne, obrazki, parafinę i żywność. Współbracia salezjanie z Przemyśla (ks. Kazimierz Piłat, ks. Władysław Kloc) czynili w Polsce zakupy liturgiczno-religijne a rodzina państwa Boczarów przewoziła. Przewieziono nawet maszynkę do wypiekania komunikantów i opłatków i monstrancję w oryginalnym opakowaniu. Ks. Bolesław Sznajder, jako proboszcz przemyski, dopomagał w kontroli celnej na przejściu i dzięki temu zaangażowaniu ks. Hoppe był w miarę zaopatrywany ${ }^{56}$.

\section{a) Litewska Socjalistyczna Republika Radziecka}

Ks. Stanisław Toporek. Jednym z najstarszych salezjanów pracujących od lat przedwojennych w Wilnie był ks. Stanisław Toporek. Z Wilna dojeżdżał do pomocy ks. dziekanowi Bolesławowi Moczulskiemu w Ejszyszkach. Po wyjeździe ks. Toporka z Wilna w 1949 roku kościół Opatrznosci Bożej przy ul. Dobrej Rady zamknięto. Ks. Stanisław podjął pracę duszpasterską w Rudnikach, Jaszunach, Porudomino, Starych Trokach, Balingródku (1956-1962) i na końcu w Ławaryszkach (1962-1977). Tu w Ławaryszkach ks. Stanisław pracował najdłużej z wszystkich dotychczasowych placówek. Po operacji na przepuklinę z plebanii do kościoła podwoził go na wózku inwalidzkim mieszkaniec z Nowej Wilejki. Wysiadajac pewnego dnia z wózka zahaczył ks. Toporek nogą, przewrócił się uderzając głową o beton i wkrótce zmarł w zakrystii 26 IX 1977 roku. Pochowany został na placu obok kościoła w Ławaryszkach, obok mogił innych kapłanów ${ }^{57}$.

Ks. Tadeusz Hoppe. Po święceniach 24 I 1943 roku w Wilnie, skierowany został po trzech miesiącach pracy w kościele Opatrzności Bożej w Wilnie przy ul. Dobrej Rady 22 na parafię w Rudnikach. Parafia jednolita wyznaniowo, bez prawosławnych i polska. Z Rudnik dojeżdżał do parafii w Porudomino i Jaszunach. Pod koniec września 1947 roku objął parafię w Solecznikach Wielkich. Tamtejszy drewniany kościół pw. św. Piotra uległ w lipcu 1944 roku spaleniu. Ks. Tadeusz postanowił go odbudować na ocalałych po pożarze fundamentach. Nieoficjalnie zaoferował mu pomoc w budowie dyrektor miejscowego kołchozu. Odbudowa świątyni w Solecznikach nie była po myśli komunistycznych władz, które zdecydowały, że powstanie tam świetlica. W dowód „uznania” za dokonane już prace ks. Hoppe otrzymał w lecie 1949 roku przeniesienie do Kalwarii Wileńskiej. Nim przybył jego następca do Solecznik - ks. Paweł Bekisz, miejscowi wierni rozebra-

\footnotetext{
${ }^{56}$ Żurek, Dziatalność duszpasterska ks. Tadeusza Hoppe w Odessie, s. 232-233.

${ }^{57}$ Żurek, Możliwości i formy duszpasterzowania salezjanów, s. 328-329.
} 
li budowlę do fundamentów, uniemożliwiając powstanie tam świetlicy młodzieżowej. Pracując ofiarnie w Kalwarii Wileńskiej ks. Hoppe jako kustosz sanktuarium maryjnego z ogromnym poświęceniem rozsławił to miejsce pielgrzymkowe na Wileńszczyźnie, a nawet całej Litwie. W 1954 roku skierowany został do parafii w Ławaryszkach, skąd na początku grudnia 1958 roku wyjechał do Odessy nad Morzem Czarnym ${ }^{58}$.

Koad. Wojciech Wiertelak. Wybuch II wojny światowej zastał go w Dworcu k. Nowogródka. Nie z własnej woli na 20 lat stał się obywatelem sowieckim. Po wojnie zamieszkał w drewnianym dworku w Rubnie k. Ławaryszek u obszarnika Jana Obsta, Niemca ożenionego z Rozalią. Pełnił funkcję zarządcy jego majątku. Trudno powiedzieć dlaczego pan Wiertelak po wojnie nie wrócił do Polski w ramach tzw. repatriacji. W czasach sowieckiej kolektywizacji rolnictwa oraz powstawania sowchozów i kołchozów, komuniści przyłączyli dworskie grunty Obsta do kołchozu. W dotychczasowym dworku Jana Obsta została otwarta szkoła. W tej sytuacji na początku lat 50. ubiegłego stulecia, wyrzucony ze swej posiadłości Obst zamieszkał w w niewielkim domu w sąsiednich Dziekaniszkach, a wraz z nim koad Wiertalak. W 1959 roku dworek został podpalony a podejrzenie władz padło na koad. Wiertelaka. W związku z tym zarzutem został pozbawiony wizy. Był to sposób na zatrzymanie go przy pracy w kołchozie jako ogrodnika, gdyż przewodniczący kołchozu nie miał lepszego fachowca na jego miejsce. Po śmierci Jana Obsta, Wojciech na początku kwietnia 1959 roku powrócił do Polski. Zamieszkał w domu salezjańskim w Płocku, gdzie przeżył jeszcze 10 kolejnych lat. Do dziś wspominają go tamtejsi mieszkańcy z Rubna i Dziekaniszek, że nie wiedzieli, iż był zakonnikiem. Był dobrym ogrodnikiem. W ostatnich latach życia Obsta nasz koadiutor nie otrzymywał za wykonywaną pracę żadnego wynagrodzenia $^{59}$.

\section{b) Białoruska Socjalistyczna Republika Radziecka}

Ks. Kazimierz Grzegorczyk. Po święceniach w Wilnie 17 XII 1941 roku, w sierpniu 1944 roku ks. Grzegorczyk został mianowany przez kurię metropolitalną czasowym administratorem parafii Trójcy Przenajświętszej w Dokszycach, dekanat Głębokie, archidiecezji wileńskiej. Kościół parafialny uległ spaleniu w 1943 roku. Msze św. odprawiał w domu parafianki Kaweckiej.

Po Dokszycach podjął pracę duszpsterską w kościele Świętej Trójcy w Głębokim. Decyzją administratora apostolskiego archidiecezji wileńskiej z dnia 17 XII 1945 roku został przeniesiony do parafii św. Andrzeja Apostoła w Łyntupach, dekanat Święciany jako proboszcz. Miejscowość Łyntupy należała do rejonu (powiatu) Postawy, obłast (województwo) Witebsk, w Białoruskiej SRR. Na począ-

${ }^{58}$ Żurek, Działalność duszpasterska ks. Tadeusza Hoppe w Odessie, s. 209-214; tenże, Oddziatywanie duszpasterskie salezjanów, s. 412.

${ }^{59}$ Żurek, ,Jeńcy na wolności”, s. 270, 273. 
tek zamieszkał prywatnie u parafian, do momentu wybudowania plebanii w 1947 roku przy kościele ${ }^{60}$.

Ks. Kazimierza nachodzili funkcjonariusze na plebanii, a wówczas najprawdopodobniej go bito, gdyż ksiądz zaczął niedomagać. Odczuwał bóle głowy, przeżywał lęki. Żył w ustawicznym strachu. Często nie nocował na plebanii, nawet wiele kolejnych nocy. Życzliwy funkcjonariusz (Rosjanin) informował potajemnie przez zaufanych parafian o planowanym aresztowaniu proboszcza. By uniknąć łapanki i wywiezienia na Sybir, nocował po domach parafian, co noc zmieniając miejsce noclegu.

Parafianie z Łyntup przedstawiajac sylwetkę zmarłego 19 XII 1959 roku proboszcza - ks. Grzegorczyka mówią: „Takich księży u nas jeszcze nie było”. Wypowiadając te słowa parafianka Weronika Piukowa płakała ${ }^{61}$.

Ks. Ryszard Stohandel jako duszpasterz w Parafianowie (1942-1948) liturgię sprawował po łacinie. $Z$ usposobienia był wesoły ale zdyscyplinowany $i$ tego wymagał od parafian. Do dziś wspominają go wierni, że raz powiedział i więcej nie powtarzał. W formacji religijnej młodzieży to umiał i „trzymał ją w lejcach”. Młodzieńcom m.in. tłumaczył jak mają się zachować podczas liturgii, np. by w kościele nie klęczeli na jedno kolano, i to skutkowało. Dziewczętom natomiast polecał by na nabożeństwa nie przychodziły w krótkich ubiorach ${ }^{62}$.

Ks. Jan Tokarski. Kościół pw. Narodzenia NMP w Dubrowej, po zamordowaniu przez miejscowych bandytów (partyzantów) dnia 20 X 1942 roku tamtejszego proboszcza - ks. Edwarda Murończyka, do końca wojny nie był obsługiwany przez żadnego duszpasterza. Po oswobodzeniu tych terenów w 1944 roku przez Armię Czerwoną przybył tam ks. Jan Tokarski, salezjanin. Zamieszkał w obszernej plebanii (wkrótce zabranej przez komunistów) naprzeciw kościoła. Obsługiwał także parafię w Pierszajach i Rakowie. Tam pracując, ,jako politycznie niebezpieczny wróg" został skazany na 25 lat łagrów sowieckich. Za co został skazany? Uzasadnienie wyroku brzmiało: ,uparty w wierze, uczył dzieci, a nie mogąc przekonać cukierkami przyciagał". Aresztowany dnia 16 VI 1948 roku, wywieziony został do Witebska k. Smoleńska w Rosyjskiej Federacyjnej Republice Radzieckiej. Tam zimno było nie do zniesienia, a spał na zamarzniętych i ośnieżonych deskach. Kolejnym miejscem zesłania był łagier w Incie - $200 \mathrm{~km}$ od Workuty, a w 1949 roku przeniesiony do miejscowości Obis nad rzeką Usą. Mszę św. odprawił na zesłaniu dopiero po pół roku, bez paramentów. Tekst Mszy św. odpisał ręcznie od więźnia-kolegi, kubek służył za kielich. Hostię i wino z rodzynek otrzymał w paczce żywnościowej, jaką przysyłali łagiernikom bliscy. W łagrze ks. Jan organizował potajemnie dla więźniów piewsze piątki miesiąca. Za to często spotykały go szykany straży łagrowej i z tego powodu niejednokrotnie bardzo cierpiał. Swoich towarzyszy zapisywał do żywego różańca i szkaplerza. Różańce z chleba wykonywały więźniarki z kobiecego łagru. Komunię świętą nosił przy

\footnotetext{
${ }^{60}$ Żurek, Możliwości i formy duszpasterzowania salezjanów, s. 334-335.

${ }^{61}$ Żurek, ,Jeńcy na wolności”, s. 68.

${ }^{62}$ Tamże, s. 172.
} 
sobie zawsze przez cały dzień, a nawet noca, by w razie potrzeby mieć Najświętszy Sakrament dla umierajacych ${ }^{63}$.

Po śmierci Stalina, na mocy amnestii dla skazanych na 25 lat, uzyskał w 1954 roku ks. Jan zwolnienie z łagru i przybył ostatecznie do Rakowa. Po kilku latach starań otrzymał „sprawkę” i pracował tu do śmierci w 1954 roku Odbył karę zsyłki 6 lat i 8 miesięcy. Oceniając później zesłanie i sprawowaną tam posługę kapłańską, z pracą duszpasterską w Rakowie, lakonicznie stwierdził: „Nie wiem gdzie praca była owocniejsza, niech Bóg to rozbiera".

Ks. Jan Wielkiewicz. Po aresztowaniu w listopadzie 1939 roku i wywiezieniu na Sybir dyrektora zakładu i proboszcza parafii w Dworcu Nowogródzkim, ks. Jana Kapusty, pozostali tam jeszcze dwaj salezjanie: ks. Ludwik Witkowski i ks. Jan Wielkiewicz. Ten ostatni wkrótce przeszedł na parafię w Nowojelni, gdzie pracował do kwietnia 1946 roku Po śmierci proboszcza i dziekana w Zdzięciole, ks. Józefa Sawickiego, ks. Wielkiewicz przeszedł do Zdzięcioła przejmując probostwo i dziekaństwo po zmarłym.

Pracował duszpastersko z wielkim zaangażowaniem na rozległym terenie parafii i okolicy. Był okazem zdrowia, stąd zdawało się, że jego energia nigdy się nie wyczerpie. Gdy w 1968 roku przyjechał w odwiedziny do Polski, widać było, że jest chory i wyczerpany. Skierowany został przez inspektora do szpitala w Łodzi. Cierpiał na niewydolność serca, nerek, oraz miał daleko posuniętą cukrzycę i schorzenie nóg. Poddany został gruntownej kuracji, która zapowiadała się na długi czas. Radzono ograniczenie dotychczasowych zajęć. Jednak gdy tylko poczuł się lepiej, zdecydował o powrocie do Zdzięcioła. Nie pomogły sprzeciwy, perswazje i serdeczne prośby wielu. Dnia 3 VI 1968 roku wyjechał do Zdzięcioła i podjął dotychczasowe duszpasterstwo. Wkrótce nastąpił nawrót choroby. Dnia 9 III 1969 roku w niedzielę odprawił chory ks. Jan ostatnią Mszę św. Gdy nazajutrz w poniedziałek przyszli wierni na Mszę św., odpowiedział im: „Niestety, ja już nie mam siły, by się z łóżka podźwignąć. Idźcie do kościoła, odprawcie sobie Drogę Krzyżowa, a ja tymczasem odmówię psalmy za konających”. Przemęczył się jeszcze do 12 marca (czwartek). O godz. 3.30 nastąiła śmierć. W trumnie wygląalał jak prymicjant ${ }^{64}$.

Pogrzeb 16 marca zgromadził ogromne tłumy. Kościół mogący pomieścić 2000 ludzi był wypełniony po brzegi. Szesnastu kapłanów spowiadało od wczesnych godzin rannych do południa, kiedy rozpoczęto egzekwie ${ }^{65}$.

Ks. Ludwik Witkowski. Ks. Witkowski pracujący od 1931 roku w Dworcu Nowogródzkim, ostatnio jako kierownik szkoły rzemieślniczej, od 1934 roku pozostawał bez urzędu. Pojawiały się u niego dolegliwosci zdrowotne (skrupuły), na skutek których nie sprawował regularnie funkcji kapłańskich. Po rozproszeniu tamtejszych współbraci w czasie wojny, ks. Witkowski, mocno zaniedbany, po-

${ }^{63}$ ASIW, T. Ks. Tokarski Jan, Ks. Stanisław Rokita, Dane o ks. Tokarskim, s. 4; Żurek, , Jeńcy na wolności", s. 184-185.

${ }^{64}$ Żurek, „Jeńcy na wolności”, s. 232; tenże, Możliwości i formy duszpasterzowania salezjanów, s. 336.

${ }^{65} \mathrm{Ze}$ względu na wybory władze nie zezwoliły na pogrzeb 14 marca. Przeniesiono go na poniedziałek - 16 marca. Żurek, , Jeńcy na wolności”, s. 232. 
woli zaczął dochodzić do formy. Po wyjeździe z Dworca do Polski ks. Wacława Rybickiego i koad. Stanisława Bacy, w czerwcu 1946 roku pozostał tam sam jeden. W Dworcu spędził prawie całe życie kapłańskie ${ }^{66}$. Mimo że niedomagał psychicznie, choroba jego nie była szkodliwa dla otoczenia, które traktowało go z wielkim zruzumieniem. Malował obrazy religijne i obrusy domowe wśród parafian. Z pomocą ks. Juliana Rykały ponownie nauczył się modlitw i sprawowania liturgii. Pracował do ostatniej chwili w parafii bardzo ofiarnie. Zmarł 2 XI 1952 roku w Dworcu. Po jego śmierci tamtejszy kościół parafialny władze komunistyczne zamknęły, gdyż parafianie nie byli w stanie płacić wygórowanych podatków ${ }^{67}$.

Ks. Jan Kapusta. Jako jedyny z grupy przedstawianych 11 salezjanów przebywał po 1939 roku przez 15 lat na terenie Związku Radzieckiego wbrew własnej woli. Został aresztowany 27 XI 1939 roku w Dworcu przez funkcjonariuszy NKWD. Wywieziony do obozu w Karelo-fińskiej obłasti pracował przy spławie drzewa. Zwolniony na mocy amnestii po podpisaniu umowy Sikorski-Majski, zglosił się do formującej się armii polskiej na terenie ZSRR pod dowództwem gen. Władysława Andersa. Skierowany został na kapelana wśród polskich wysiedleńców w Kazachstanie, następnie w Uzbekistanie. W sierpniu 1942 roku aresztowany w Iranie pod zarzutem szpiegostwa. Odesłany do Moskwy i tam skazany na 10 lat łagru w Workucie. Po odbyciu kary w 1952 roku zesłany został na bezterminową zsyłkę do krasnojarskiego obwodu. Tam doczekał się uwolnienia. Wrócił do Polski ostatniego dnia grudnia 1955 roku. Starania o uwolnienie i powrót do Polski trwały 9 lat $^{68}$.

\section{c) Ukraińska Socjalistyczna Republika Radziecka}

Z Ławaryszek na nowe miejsce pracy do Odessy ks. Hoppe wyjeżdżał na początku grudnia 1958 roku $\mathrm{z}$ Wilna pociagiem $\mathrm{z}$ bagażem w rękach. Jechał w nieznane, odczuwał pewne ryzyko, a na twarzy widać było zdenerwowanie. Przejął w Odessie kościół św. Piotra po ks. Witoldzie Bronickim. Zamieszkał w skromnym mieszkaniu w suterenach kościoła, pod prezbiterium. Podczas każdej Mszy św. głosił Słowo Boże. Wspaniała katedra pw. Wniebowzięcia NMP była już wówczas zamknięta ${ }^{69}$.

Przez ponad 7 lat dojeżdżał z Odessy do Kijowa, do powstałego tam ośrodka duszpasterskiego.

„Po owocach ich poznacie”. Widocznym owocem pracy księdza prałata Hoppe w Odessie mogą być chociażby miejscowe powołania kapłańskie i zakonne -

${ }^{66}$ Po święceniach 9 VII 1928 roku pracował do lata 1931 roku jako katecheta domu w Wilnie, ul. Stefańska 41.

${ }^{67}$ Żurek, ,Jeńcy na wolności”, s. 289; tenże, Możliwości i formy duszpasterzowania salezjanów, s. 336-337.

${ }^{68}$ Żurek, „Jeńcy na wolności”, s. 126; tenże, Możliwości i formy duszpasterzowania salezjanów, s. 336.

${ }^{69}$ Tak wspomina pożegnanie z ks. Tadeuszem ks. Obrębski. Żurek, ,,Jeńcy na wolności”, s. 95, 327-328. 
salezjanie: diak. Aleksander Czumakow (diakonat w 1984 obrz. biz.-ukr.), ks. Andrzej Janicki (wyśw. 1987), ks. Witalis Krzywicki (1997), ks. Marian Kuc (2001), ks. Edward Zajączkowski (2002), ks. Tadeusz Zajączkowski (2006, kapłan diecezjalny), s. Anna Zajączkowska $\mathrm{CMW}^{70}$.

\section{d) Mołdawska Socjalistyczna Republika Radziecka}

Ks. Bronisław Chodanionek. Na terenie republiki mołdawskiej po wojnie mieszkało ok. 25 tys. katolików obrządku łacińskiego narodowości niemieckiej i polskiej. W stolicy republiki - Kiszyniowie Polaków mieszkało niewielu, więcej na prowincji. Po śmierci w 1948 roku tamtejszego duszpasterza, ks. Mikołaja Szczurka, władze komunistyczne wyraziły zgodę na podjęcie tam pracy przez salezjanina ks. Bronisława Chodanionka. W 1949 roku wyjechał on z parafii Porudomino (Litewska SRR), by w odległym o ponad tysiąc kilometrów Kiszyniowie objąc kościół pw. Niepokalanego Poczęcia NMP w centrum miasta. Zamieszkał we własnym domu przy ul. Stalingradzkiej. Do kościoła dojeżdżał motocyklem. Ks. Chodanionek, podobnie jak ks. Szczurek, był jedynym kapłanem obrządku łacińskiego w Mołdawii liczącej 4 mln ludności ${ }^{71}$.

Do kościoła przychodzili głównie starsi. Młodzież jako niepełnoletnia była z kościoła wyprowadzana przez nauczycieli i osoby do tego oddelegowane. To jednak nie zniechęcało w gorliwości tamtejszego duszpasterza. Szczególną troskę okazywał dzieciom. Z Wileńszczyzny, gdzie uprzednio pracował (Ejszyszki), przywożono do Kiszyniowa dzieci, które ks. Bronisław starannie przygotowywał do spowiedzi i I Komunii św. Okazywał szczególną troskę o dzieci. Jeśli posiadał, to obdarowywał ich medalikami i obrazkami religijnymi.

$\mathrm{Z}$ dalekiego miejsca pracy odwiedzał rodzinne strony (Kolonię Premiany, Stolicę). W czasie takich „wizyt-odwiedzin” połączył sakramentem małżeństwa wiele rodzin i chrzcił ich dzieci. Mimo ciężkich czasów, sprawował te funkcje prywanie, licząc się z ewentualnymi konsekwencjami. Zainteresowani orientowali się dokładnie, kiedy ksiądz rodak ma przyjechać i przygotowywali się do przyjęcia sakramentów. Niejednokrotnie nie czekając na jego przyjazd całymi rodzinami udawali się do niego na Mołdawię w tym samym celu.

W 1957 roku po zamknięciu przez władze kościoła, mającego odtąd pełnić funkcję kino-teatru, ks. Bronisław odprawiał w kaplicy ormiańskiej na cmentarzu, wówczas już zamkniętym. Na starsze lata planował nawet wyjazd na stałe do Polski. Miał skompletowane już dokumenty. W krótkim czasie zachorował i zmarł 25 XI 1973 roku, w wieku 63 lat. Zmarł z przepracowania dla chwały Bożej i dla dobra wiernych. Te dwa ideały zawsze zwyciężały u niego, ilekroć w chwilach

${ }^{70}$ Żurek, Działalność duszpasterska ks. Tadeusza Hoppe w Odessie, s. 223, tenże, Oddziaływanie duszpasterskie salezjanów, s. 437.

${ }^{71}$ Żurek, Możliwości i formy duszpasterzowania salezjanów, s. 326. 
utrudzenia ewangelicznego przychodziła pokusa, by powrócić do kraju i podjąć w Zgromadzeniu życie wspólne, za którym tęskni $7^{72}$.

Mimo życia kapłańskiego i salezjańskiego w pojedynkę i wyłącznie na placówkach duszpasterskich, ks. Bronisław zachował w sobie i sposobie życia cechy powołania salezjańskiego i życia wspólnotowego. Po jego śmierci w 1974 roku, charakteryzując jego sylwetkę, ks. Witold Golak z Woźniakowa powiedział: „Co określało ujmującą sylwetkę śp. ks. Bronisława, to jakaś dziwna bezinteresowność, połączona z nieśmiałością, która raczej okazywała się delikatnością. We współżyciu był bardzo uprzejmy, uczynny, zawsze taktowny. W życiu wspólnotowym był obserwantem, co było wynikiem jego wielkiego ukochania powołania salezjańskiego. Nic też dziwnego, że okazywał zdyscyplinowanie objawiające się w punktualności wzorowej, sumienności w odprawianiu ćwiczeń duchownych, w przestrzeganiu porządku dnia. Wszystko to łączył z pobożnością bez egzaltacji"'73.

Był bardzo przywiązany do Zgromadzenia. Odczuwał nieustanną tęsknotę za życiem wspólnotowym, ale nie zdołał powrócić do kraju, gdyż - jak powtarzał obawiał się ulec pokusie, by nie pozostać w Ojczyźnie na stałe, jak to się zdarzyło innym współbraciom. Uznawał zasadę: pracować dla dobra dusz bez oszczędzania $\operatorname{sie}^{74}$.

Wspomniani salezjanie po 1945 roku podjęli jedyną możliwą wówczas prace duszpasterską na terenie republik Związku Sowieckiego. Przez pasterzy diecezji byli traktowani jako kler diecezjalny, gdyż nie przełożeni zakonni decydowali o ich przeznaczeniu na poszczególne parafie. Nigdy jednak nie przestali się czuć salezjanami. Utrzymywali na możliwe sposoby kontakt z przełożonymi prowincji, interesowali się życiem i działalnością Zgromadzenia w ogóle. Nierzadko z tej okazji współbracia ze Wschodu przekazywali pomoc finansową przełożonym w kraju, głównie w formie stypendium intecji mszalnych, których mieli oni wystarczająco. Chociaż nie mogli pracować w zakładach salezjańskich, we właściwym tego słowa znaczeniu, jednak formacja otrzymana w Zgromadzeniu i studia teologiczne dawały im możność pracy duszpasterskiej. Ofiarna posługa duszpasterska wobec dorosłych, gdyż tylko tacy w Związku Radzieckim mogli być praktykującymi katolikami, przekładała się na formację duchową ich dzieci i wnuków. Sakramenty inicjacji chrześcijańskiej, najczęściej sprawowane potajemnie przyjmowali najmłodsi dzięki odpowiednio uformowanym rodzicom. Przygotowanie do I Komunii świętej i bierzmowania prowadzili nie kapłani ale rodzice i dziadkowie lub osoby cywilne do tego przygotowane i na odpowiedzialność rodziców.

${ }^{72}$ Tak ocenił ks. Toporek, który go znał od kleryka. Żurek, „Jeńcy na wolności”, s. 51; tenże, Możliwości i formy duszpasterzowania salezjanów, s. 378-379.

${ }^{73}$ Cyt. za: Żurek, „Jeńcy na wolności”, s. 52; tenże, Możliwości i formy duszpasterzowania salezjanów, s. 326-327.

${ }^{74}$ Żurek, ,Jeńcy na wolności”, s. 52. 
Z całą więc stanowczoscią można powiedzieć, że salezjanie pracujący w duszpasterstwie w czasach radzieckiej rzeczywistości pracowali zgodnie ze swoją profesją, oddziałując pośrednio także na dzieci i młodzież, z istoty samego duszpasterstwa parafialnego. W kazaniach poruszali tematykę zagrożenia ateistycznego wobec wszystkich, a głównie na młodzież i dzieci, które niejednokrotnie kształcone i wychowywane w szkole ateistycznej były najbardziej podatne na tego rodzaju propagandę. A właściwą ich formację duchową przejmowali rodzice.

Wspomniani wyżej współbracia, pracując w warunkach ekstremalnych, spełniali swoją misję kapłańską i salezjańską w duchu zgromadzenia salezjańskiego, którego byli wiernymi członkami do swej śmierci.

\section{DIE POLITISCH-SOZIALEN BEDINGUNGEN DER SALESIANISCHEN ERZIEHUNGS- UND SEELSORGETÄTIGKEIT IN DEN REPUBLIKEN DER SOWJETUNION NACH 1945}

\section{Zusammenfassung}

Die Kirche als Gemeinschaft des Volkes Gottes nimmt immer wieder in Erwägung ihre Präsenz in der Welt und die erfolgreiche Verkündigung des Evangeliums, für die der Mut und der verantwortungsvolle Einsatz vieler Glaubensapostel als Halt und Inspiration gelten. Nicht selten mussten diese Glaubensverkündiger, oft schwierigen zeitgemäßen Umständen ausgesetzt, unter Beistand des Heiligen Geistes auch das Kreuzopfer auf sich nehmen. Diesem Opfer mussten sich auch die polnischen Salesianer preisgeben, die weiterhin auf den, ihnen schon fremd gewordenen, ehemaligen polnischen Gebieten ausharren wollten.

Nach dem zweiten Weltkrieg hat Polen die von der Sowjetunion annektierten Ostgebiete verloren. Demzufolge hatten die den dortigen zwei Provinzen angehörenden (Hl. Stanislaus Kostka-Privinz und Hl. Jacek-Hyazinth-Provinz) Salesianer, 11 Ordenshäuser einbüssen müssen. Nachdem die meisten dortigen Polen zur so genannten Repatriierung gezwungen wurden, was Aussiedlung nach nunmehr kommunistisch regierten Polen bedeutete, sind 11 Salesianer in der Fremde geblieben, darunter 9 aus eigenem Willen. Die letzteren, taten dies um die dort weiterhin lebenden Katholiken, hauptsächlich Polen, seelsorglich zu betreuen. Diese Leute mussten doch im kommunistischen Staat wohnen, wo Religion und Kirche einer unablässigen Verfolgung unterzogen waren und der Glaube aus den Herzen und Gemütern mit allen Mitteln ausradiert sein sollte.

Aus dem Wilnaer Gebiet (Litauische Sozialistische Räterepublik), wo sich bis 1945 der Seelsorgeeinsatz der Salesianer konzentrierte, wurde er nunmehr auf andere Sowjetische Republiken ausgeweitert, nämlich: Weißrussland, Ukraine, Moldawien. In den Jahren ihrer Seelsorge auf dem Gebiet der Sowjetunion blieben die dortigen Salesianer im Kontakt mit den Ordensbrüdern und Vorgesetzten in der polnischen Heimat. Kein einziger hat seine Pfarrkinder verlassen. Durch schwere Arbeit, Krankheiten und Nöte abgerieben, unter ständigem Druck der gottlosen Gesetzgebung lebten sie und starben in der Fremde als wahrhafte Apostel Christi, Zeugen der Kirche. Sie erwarten dort auf die allgemeine Auferstehung von den Toten. 